

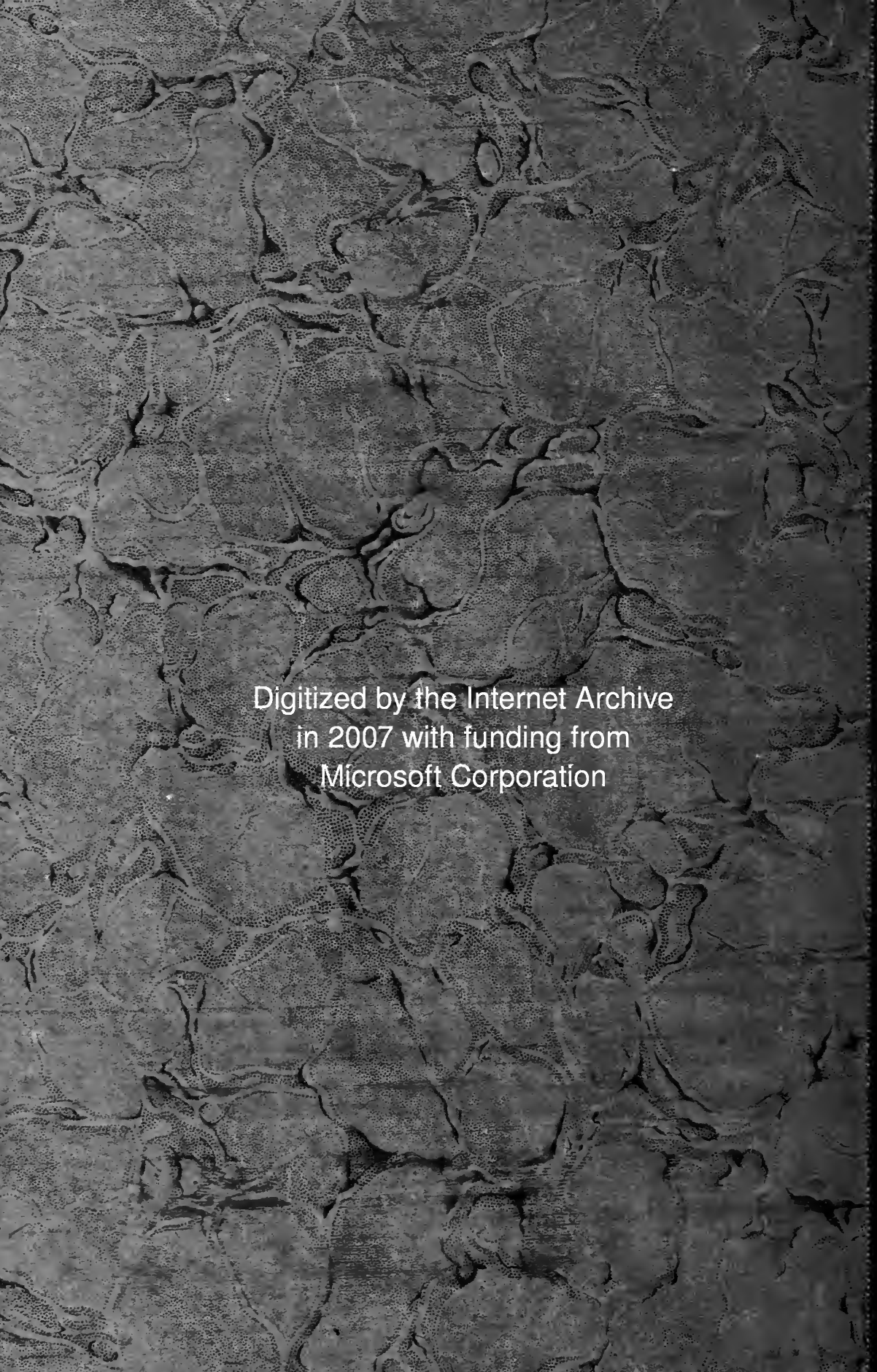

htto:/www archive org/details/principlesofinte00inteuoft 


\section{$1613 p$}

SUPPLEMENT TO THE MAÎTRE PHONÉTIQUE SEPT.-OCT. 1912

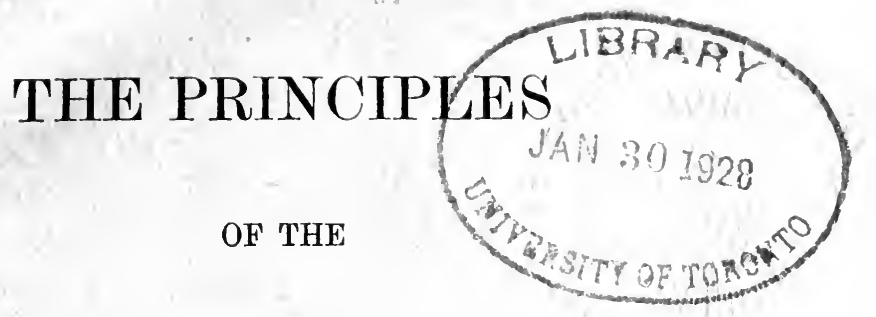

INTERNATIONAL PHONETIC

\section{ASSOCIATION}

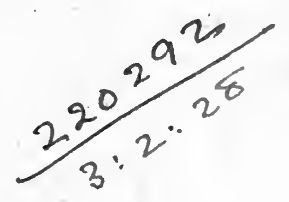

OBTAINABLE FROM THE EDITORS:

\section{PAUL PASSY}

20 RUE DE LA MADELEINE, BOURG-LA-REINE (SEINE), FRANCE.

\section{DANIEL JONES}

UNIVERSITY COLLEGE, GOWER STREET,

- LONDON, W.C.

1912

Price Sixpence 


\section{CONTENTS.}

History and Aims of the Association.

Constitution of the Association

The Council

Membership

Subscriptions

Phonetic Writing and its uses

The International Phonetic Alphabet . . . . . . . . . . . 8

Values of the International Phonetic Symbols. . . . . . . . . . . 9

'Narrow' and 'Broad' Transcription . . . . . . . . . . . . 14

Principles of 'Trauscription for languages hitherto not transcribed . . 16

Further developments. . . . . . . . . . . . . 17

Specimens

Southern English. . . . . . . . . . . . 19

Northern English.................. 21

Scotch Pronunciation. . . . . . . . . . . 21

American English ............... . . 22

French . . . . . . . . . . . . . . 22

German . . . . . . . . . . . . . 23

Italian . . . . . . . . . . . . . . . . 23

Spanish .................... . . 24

Portuguese. . . . . . . . . . . . . . 24

Catalanian . . . . . . . . . . . . . . . . . . . 24

Welsh . . . . . . . . . . . . . . 25

Swedish . . . . . . . . . . . . . 25

Russian . . . . . . . . . . . . . . . . . 26

Polish . . . . . . . . . . . . . . . . 26

Czech ....................... 27

Hungarian . . . . . . . . . . . . . . 27

Finnish . . . . . . . . . . . . . . . . 27

South African Dutch . . . . . . . . . . . . . 28

Urdu . . . . . . . . . . . . . . . . . 28

Panjabi .................... . . 29

Chinese . . . . . . . . . . . . . . 30

Burmese . . . . . . . . . . . . . . 30

Phonetic Spelling ... . . . . . . . . . . 31

List of the Principal Works in which the International Phonetic Alphabet

is employed ................... 32

Script forms of phonetic symbols . . . . . . . . . 40 


\section{THE PRINCIPLES}

OF THE

\section{INTERNATI0NAL PHONETIC ASSOCIATION}

\section{HISTORY AND AIMS OF THE ASSOCIATION}

1. The International Phonetic Association is a Society consisting of persons interested in the science of phonetics. Its main objest is to promote the scientific study of phonetics and the various practical applications of that science.

2. The Association was founded in 1886. In 1888, after consulting the opinion of its members, the Association drew up an International Phonetic Alphabet, by means of which the pronunciation of any language may be accurately represented. This alphabet has been used ever since (with a few additions and improvements) in the Maître Phonétique, the official organ of the Association (see § 16).

3. The system has also become very widely used by language teachers and others outside the Society, in fact, this alphabet is at the present time far more widely used than any other phonetic system and bids fair to become universal ${ }^{1}$ ). There are several hundred books in which the International Phonetic Alphabet is used; the more important works, about 200 in number, are mentioned in the bibliography ${ }^{2}$ ) (p. $32 \mathrm{ff}$.).

4. Among the publishers and printers possessing International Phonetic types may be mentioned the Clarendon Press, Cambridge University Press, London University Press, Wm. Clowes (London),

1. For statistics with regard to England see The Means of Training in Phonetics available for Language Teachers by L. H. Althaus, page 6, (published by the Association, price $6 \mathrm{~d}$ ). See also bibliography, p. $32 \mathrm{ff}$.

2. One publisher (Groos of Heidelberg) has issued over 70 books in which Interuational Phonetic Script is used. 
Turnbull and Spears (Edinburgh), Teubner (Leipzig), Reisland (Leipzig), Hesse \& Becker (Leipzig); Didier (Paris), Gyldendal (Copenhagen). Messrs Wm. Clowes are about to cast a fount of International Phonetic type which will be specially approved by the Council of the Association ${ }^{1}$ ). Typowriters containing International Phonetic types are supplied by the Ideal Typewriter Co. (115 ${ }^{a}$ Queen Victoria St., London, E. C. $\left.)^{2}\right)$.

5. Among the languages which have been transcribed by means of the International phonetic alphabet are: English, French, German (with numerous dialects of each), Dutch, Italian, Spanish (including Chilian), Portuguese, Catalanian, Roumanian, Latin, Greek, Norwegian, Danish, Swedish, Icelandic, Finnish, Hungarian, Russian, Polish, Czech, Lettish, Ẅelsh, Breton, Syriac, Arabic, Urdu, Panjabi, Chinese (both Mandarin and Cantonese), Japanese, Burmese, Javanese Zulu, Odjibway (North American Indians), Aleutian.

6. It must be understood, however, that the Association is in no way bound to its alphabet. Not only are its members at liberty to use any other system they may prefer (except in the Maître Phonétique), but they are invitep to suggest such alterations and improvements as they may think desirable. Such suggestions are often discussed in the Maître Phonétique and may be submitted to the Council at the annual consultation (\$16).

7. The Association has always favoured a radical reform of language teaching by the adoption of "direct" or "inductive" methods, and has played no small part in bringing about the present widespread use of these methods.

8. The principles of the Association, as regards the teaching of foreign languages, are summed up in the following six $\left.\operatorname{articles}^{3}\right)$ :

(i). The first thing to be studied in a foreign language is not the more or less archaic language of literature, but the spoken language of ordinary conversation.

1. Messrs Clowes will be prepared to sell these types for export.

2. Two machines are issued (1) a "Bijou Phonetic" Typewriter containing (in addition to the ordinary letters) the phonetic types required for the ordinary transcription of English, French und German, price $\mathfrak{E}_{13.13 .0}$, and (2) a "Complete International Phonetic" Typewriter containing (in addition to the ordinary letters) the whole of the International symbols price $£ 27.10 .0$. A special discount of $£ 1$ on each machine is allowed to members of the Association. Members wishing to avail themselves of this arrangement should apply to the headquarters of the Association.

3. These articles embody the general tendencies of the Association and not the individual opinion of each member. 
(ii). The teacher's first care slould be to make his pupils perfectly familiar with the sounds of the foreign language. To ensure a correct use of the foreign sounds he will make use of a phonetic transcription, which should be employed to the exclusion of the traditional spelling during the initial stages.

(iii). The teacher's next aim should be to impart a perfect command of the commonest phrases and idioms of the foreign language. To obtain this result he will use connected texts, dialogues, descriptions and narratives, all as easy, natural and interesting as possible.

(iv). Grammar will at first be taught inductively, by grouping together and drawing general conclusions from such facts as are observed in reading. A more systematic study is to be kept for a later stage.

(v). The teacher will endeavour to connect the words of the foreign language directly with the ideas they express, or with other words of the same language, not with those of the mother tongue. Translation will therefore be replaced, as far as possible, by objectlessons, picture-lessons, and explanations in the foreign language.

(vi). When, at a later period, written work is introduced it will consist at first of the reproduction of matter already read and explained, then the reproduction of stories, etc., which the pupils have heard the teacher tell; free composition will come next; translation from and into the foreign language is to be kept till the end.

9. The Association also recommends the use of phonetics and phonetic transcription in connexion with the teaching of the mother tongue, particularly for the purpose of studying dialectal peculiarities and correcting the indistinctness and artificialities which unfortunately mar the pronunciation of so many. The Association also recommends the use of phonetic script in connexion with the teaching of reading.

10. The Association has also done much towards encouraging phonetic research. Many important works on philology and other branches of language study have been written by its members. It is largely owing to the influence of the Association that courses of instruction in phonetics have been instituted at various universities, and that "applied phonetics" has become a prominent feature of nearly all holiday-courses for teachers.

11. The Association has instituted an official examination in phonetics, and grants a diploma to persons attaining a certain standard. (Particulars may be obtained from the secretaries.) 
12. Though not directly concerned with Spelling Reform, the Association regards with favour the work of the various spelling reform Societies, and has been able to help the movement indirectly by showing up the imperfections which are to be found in the current spelling of most languages.

13. Finally, it may be stated that the constant intercourse between the members of the Association has tended to create among language teachers all over the world a spirit of good feeling, which is as conducive to scientific progress as to the advancement of peace between nations.

\section{CONSTITUTION OF THE ASSOCIATION}

14. The Association is governed by an International Council of 30 , elected by the members every other year.

15. The following is a list of the members of the Council for 1912-1913. Those marked * are members of the Executive Committee.

President: W. Vietor, Ph. D., M. A., Professor of English at the University of Marburg, Germany.

Vice-Presidents: 0. Jespersen, Ph. D., Professor of English at the

University of Copenhagen; E. R. Edwards, Docteur de l'Université de Paris, H. M. Inspector of Schools, London.

Secretaries: *Paul Passy, D. ès L., Professor of Phonetics at the Ecole des Hautes Etudes, Paris; *Daniel Jones, M. A., Lecturer on Phonetics at University College, London.

Treasurer: *Mlle S. Lund, language teacher, Bourg-la-Reine, France.

Other members of the Council: Jose Ma Arteaga Pereira, Barcelona; A. T. Baker, M. A., Ph. D., Professor of French at the University of Sheffield; J. Cameron, Professor of Romance Languages at University College, Toronto, Canada; A. Camilli, Rome; *C. Cloos, French and British Consul, Frederiksharn, Denmark; A. Frinta, Ph. D., Plzeň, Bohemia; C. Grandgent, Professor of Romance Languages, Harvard University, Boston, U.S.A.; R. Lenz, Ph. D., Director of the Pedagogical Institute, Santiago, Chili; E. A. Meyer, Ph. D., Lecturer on German at Handelshogskolan, Stockholm; E. Nader, language teacher, Vienna; A. Rambeal, Assistant Professor of Romance languages at the University of Berlin; W. Rippmann, M. A., Professor of German at Queen's College, London; Th. Rosset, 
Professor of French Philology at the University of Grenoble, France; L. Šcerba, Lecturer at the University of St. Petersburg; Frk. E. Simonsen, Copenhagen; *J. Spieser', pastor, Waldhambach i. Elsass, Germany; Ch. Thudichum, Director of the International College, Geneva; W. Tilly, Groß-Lichterfelde-West, Berlin; 0. J. Tallgren, Helsinki, Finland; A. R. G. Vianua, Corresponding member of the Academy of Science, Lisbon; F. Waterhouse, Senior Lecturer in modern languages at the Teachers' College, Sydney, Australia; R. Weeks, Professor of French at Columbia University, New York; A. Western, Ph. D., Headmaster of the High School, Frederiksstad, Norway; J. A. Yates, M. A., H. M. Inspector of Schools, Waltair, India.

16. Any questions that may arise regarding the policy or the administration of the Association, the adoption of new symbols, the alteration of existing symbols, etc., are referred to the Council at an annual consultation. Members desiring to bring any matter before the Council may apply to one of the Secretaries.

17. The Association now (August 1912) numbers over 1500 members. The members are distributed as follows: - England about 400, Germany about 350, United States about 120, France about 100, Denmark about 80, Austria-Hungary, Switzerland, Chili about 50 each, Sweden, Canada about 40 each, Italy about 30. There are also representatives of the following countries: - Holland, Belgium, Luxemburg, Spain, Portugal, Norway, Iceland, Finland, Russia, Poland, Turkey, Roumania, Brazil, Cuba, Costa Rica, Egypt, South Africa, India, Dutch East India, IndoChina, China, Japan, Australia, New Zealand.

18. Persons may join the Association either as 'ordinary' members or' as 'active' members.

19. Ordinary Members receive free of charge the 'Maitre Phonétique', the official organ of the Association (Editor: P. Passy, 20 Madeleine, Bourg-la-Reine, Seine, France; Assistant Editor: D. Jones, University College, London). The 'Maître Phonétique' is issued on the $30^{\text {th }}$ of January, March, May, July, September and November of each year. It contains articles in various languages the International alphabet being used throughout. The articles deal with all branches of Phonetics and its applications, and give information respecting the progress made by the science in different parts of the world. The best methods of language-teaching are also discussed, and special texts suitable for students are given. 
20. Every ordinary member is entitled to a vote at the election of members of the Council.

21. Every ordinary member whose subscription has been paid by Jan. $1^{\text {st }}$ is entitled to 10 lines of free advertisement in the Maître Phonétique in the course of the year.

22. Active Members are those who are willing to work actively in the interests of the Association. They receive two copies of every Maitre Phonétique, the additional copies being intended for propaganda purposes. Active members are eligible to serve on the Council, and are entitled to two votes at the elections.

23. Every active member whose subscription has been paid by Jan. $1^{\text {st }}$ is entitled in the course of year to 25 lines of free advertisement in the Maître Phonétique.

24. The Annual Subscriptions are:

For Ordinary Members 3 francs 50 c. $(=2$ s. $10 \mathrm{~d}$. $=70$ cents $=\mathrm{Kr} .2 .50$ [Scandinavian] $=\operatorname{Rs} 2$ as. 2).

For Active Members 6 francs $(=4$ s. 10 d. $=1$ dollar 20 c. $=\mathrm{Kr} .4 .20$ [Scandinavian] $\Rightarrow$ Rs 4 as. 4 ).

25. Subscriptions are due on the $1^{\text {st }}$ of January each year. They may be paid to D. Jones, Esq., University College, London, W. C., or direct tosthe Treasurer, Miss S. Lund, 27 Grande Rue, Bourg-la-Reine, Seine, France.

\section{PHONETIC WRITING AND ITS USES}

26. When the written form of a language represents with accuracy the pronunciation of the spoken language, the writing is said to be phonetic.

27. The principle of phonetic spelling is carried out consistently in many English words, e. g. in, on, cat, dog, put, leg, strip, fulfil, itself; bandit. But many other words are written quite unphonetically in current spelling: thus the first letter is silent in hour and the last in lamb; right and write are sounded alike but written differently; lead (noun) and lead (verb) are spelt alike but sounded differently. The current spelling of some languages is, at present, not far from phonetic; such are Italian, Spanish, Dutch, Croatian, Hungarian, Finnish. Others, such as English, French and Danish, are quite the reverse. It is, however, possible to write phonetically any language or in fact any variety of any language.

28. It has long been known to specialists that a phonetic system of writing is necessary for some objects; for instance, 
shorthand, and the comparative study of languages or dialects. More recently, educationists have discovered that phonetic spelling could be used with great advantage in connexion with the teaching of foreign languages. For when a foreign language is taught by means of the traditional spelling, the pupils are constantly hampered by the contradictions between the spoken and written forms of the same words. When, on the other hand, the spoken words are accurately represented by means of a phonetic transcription, they are easily memorized, and the progress is much more rapid.

29. The advantages to be derived from the use of a phonetic transcription in connexion with language teaching are, however, now too well known to need much comment. It has been proved by countless experiments that persons who have made extensive use of phonetic theory and phonetic transcription ${ }^{1}$ ), when studying a foreign language, generally have a far better pronunciation of the language than those who have only worked with the current spelling and imitation. There is also abundant evidence to show that the transition from phonetic transcription to ordinary spelling is not a difficult matter, and that pupils who have been thoroughly trained to write a foreign language phonetically are generally able to write the current spelling more accurately than those who have had no such training ${ }^{2}$ ).

30. A phonetic transcription is still more necessary to a student who endeavours to grapple with a foreign language without the help of a master. It enables him to work at any language without puzzling at every word to know how he should read it This comes out most clearly in languages with a difficult or complicated system of writing, such as Chinese, Japanese, Burmese, Arabic or Syriac.

31. Further, a phonetic system is necessary for recording languages hitherto unwritten (see $\S \S 68-76$ ). In this way it is of the utmost value to travellers, missionaries, and officials in distant colonies; likewise to those who are interested in that most fascinating branch of philology, the study of country dialects.

1. Phonetic theory teaches the student how to form the foreign sounds. Phonetic transcription teaches him how to use the right sound in the right place.

2. See V. Partington, The Transition from Phonetic to Ordinary Spelling (published by the Association, price $7 \mathrm{~d}$, to members $4 \mathrm{~d}$ ). 
32. Phonetic writing may also be used with advantage in elementary school work, for teaching children to read the mother tongue. Learning to read by the usual methods is at best a long and dreary task; but where phonetic texts are used it becomes short and easy ${ }^{1}$ ). When once a child reads phonetic texts fluently, the transition to the common spelling is shown by experience to be a matter of no great difficulty.

33 For the above reasons it is clear that every teacher, every educationist, every philanthropist or social reformer, should have at least some idea of what phonetic writing is; more particularly as, notwithstanding its foreign and somewhat startling appearance, its principles can be mastered in a few minutes, and tolerable fluency in reading it can be acquired in a few hours.

34. Finally, a thorough knowledge of phonetics and experience in the use of phonetic transcription is indispensable to all students of philology. Many of the most important changes in language have remained unrecorded either because there was no writing at the time or because the spelling was fixed and did not reflect the changes in the words. By using a phonetic transcription the nature of such changes may be clearly demonstrated ${ }^{2}$ ).

\section{THE INTERNATIONAL PHONETIC ALPHABET}

35 . We can write phonetically in various ways. For instance, to express the first sound of the words can, keep, quick, we can choose any of the letters $c, k$, or $q$, as long as we are consistent, and always use the same letter for the same sound. We can write phonetically equally well with Roman or Gothic or Russian or Greek or Armenian or Sanscrit letters. As a matter of fact, shorthand writers write phonetically with a set of letters quite different from the ordinary letters of the alphabet.

36. The system described in the following pages is the international system referred to in $\S 2$, and is recommended for general use. It is based upon the Roman alphabet, which is used by the great majority of civilized nations, - this alphabet being supplemented by a certain number of new symbols, just as the English

1. Seo particularly J. Spieser, Ein Klassenversuch (Scheffer, Leipzig) $2^{\text {nd }}$ ed., 1912; also Das begriffliche Lehvverfahren insbesondere beim Lesenlehren by the same author (obtainable from the Secretaries of the Association).

2. See the books in section VIII of the bibliography (p. 38). 
add $k, w, x$ and $y$, to the 22 letters used in Italian, and as the Icelanders use the two letters $b$ and $\partial$ for the two sounds of the English th.

37. Further, this alphabet is based on international usage; that is, it gives to each letter as far as possible, the value it has for the majority of peoples using the Roman alphabet. Thus $\mathbf{z}$ is used for the sound of English zeal, which agrees with English, French and Dutch, but is contrary to German, Italian and Spanish usage; and $\mathbf{v}$ is used for the first sound in veal, according to English, French, Italian and Scandinavian usage, but contrary to German and Spanish. On the other hand, $\mathbf{j}$ has been taken for the first sound in yet, contrary to English, French and Spanish, but in accordance with German, Italian, Dutch and Scandinavian usage. In the International system the vowel letters $\mathbf{a}, \mathbf{e}, \mathbf{i}, \mathbf{o}$ and $\mathbf{u}$ have, roughly speaking, what are called the Italian values.

38. This redistribution of letters according to international usage necessarily produces some forms that are startling at first sight. An Englishman, for instance, cannot help being startled when he sees jiist written for yeast and haus for house. But it does not take long to accustom oneself to the international values of the letters, and once the difficulty is overcome, the advantages of using the same system for all languages are incalculable.

\section{VALUES OF THE INTERNATIONAL PHONETIC SYMBOLS}

39. We now give a table of the International phonetic symbols. They are arranged according to the mode of formation of the sounds which they represent.

40. The values of most of the symbols may be seen from their positions on the table. Thus, the phonetic symbol p, being in the column 'lips' and in the row 'plosive' denotes an explosive sound formed by the two lips (i. e. the usual sound of the letter $p$ ). Similarly the phonetic vowel-symbol $\mathbf{i}$, being in the column 'front' and in the row 'close', denotes a type of vowel sound in which the front of the tongue ${ }^{1}$ ) is raised high in the direction of the hard palate (for instance the second vowel sound in machine).

1. The 'front' of the tongue is defined in phonetics as the part of the tongue opposite the hard palate, when the tongue is in the position of rest. 


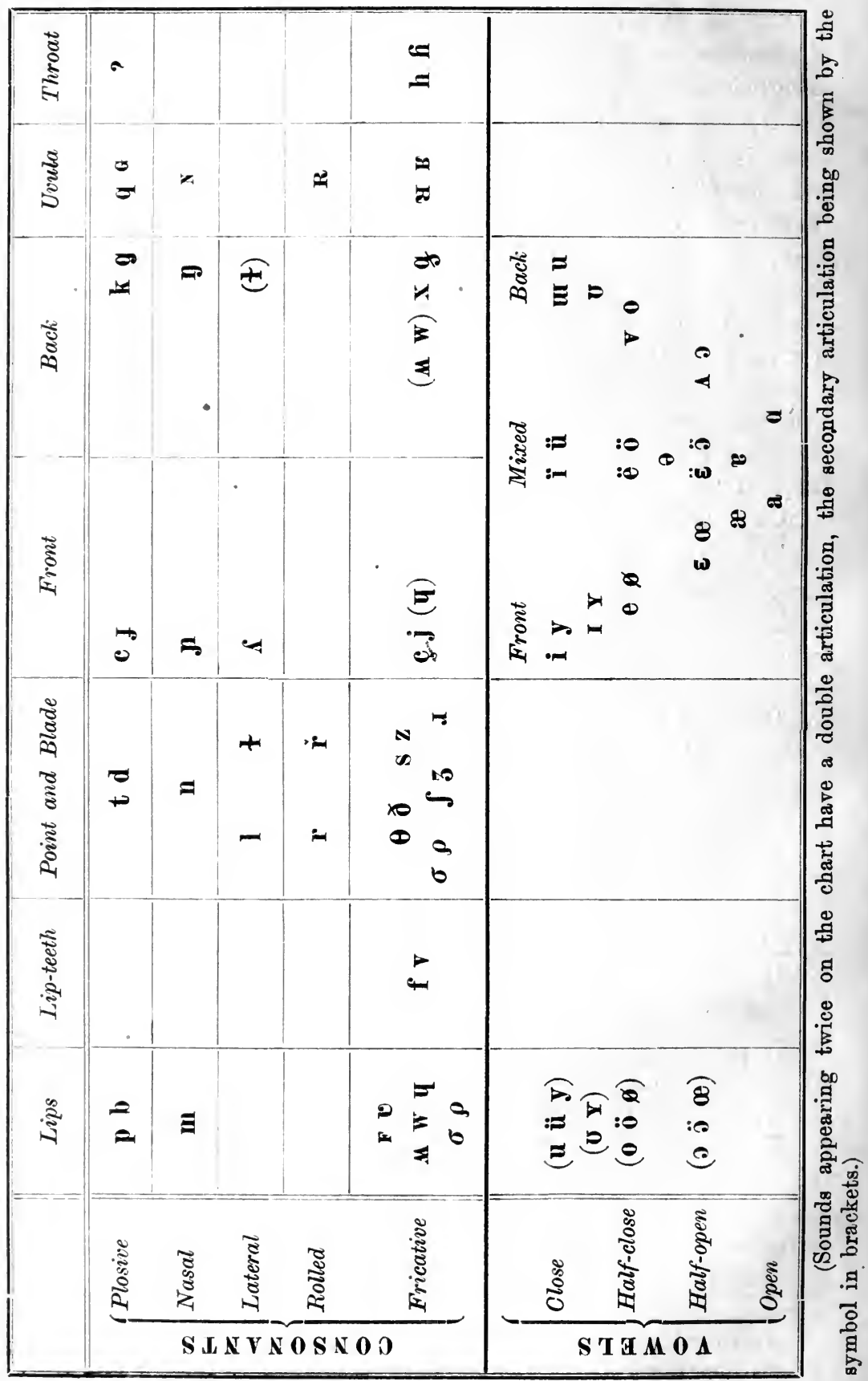


41. The above table appears somewhat complicated because it includes the symbols for all languages to which the International system has as yet been applied. A table of the sounds of one language only would be far simpler. Such tables will be found in many of the books mentioned in the bibliography.

42. We append some further brief indications of the values of those symbols whose value is not self-evident.

43. Consonants. The front plosive consonants $\mathbf{c}, \mathfrak{f}$ are heard in the Hungarian words kotya, Magyar; they may sometimes be observed in dialectal French in such words as qui, gai (ci, Je for the standard ki, ge); they are the sounds meant in some novels by the spellings kyart, gyard (for cart, guard), representing pronunciations formerly current in vulgar speech. - $q$ is the deep Arabic $q a f .-?$ is the 'glottal stop', i. e. the explosive sound heard (in an exaggerated form) in coughing; the sound is heard in North German pronunciation before initial stressed vowels; it is the Danish stød, Arabic hamza.

44. $\mathbf{n}$ is the $g n$ of French montagne, Italian ragno, Spanish $\tilde{n}$, Portuguese $n h ; \boldsymbol{y}$ is the English and German $n g$ of ring, $\mathbf{x}$ is a uvular nasal occurring in Eskimo. m may be used, when necessary, to represent the lip-teeth nasal. - $\boldsymbol{\Lambda}$ is the Italian $g l$ of egli, Spanish $l l$, Portuguese $l h$; $\mathbf{t}$ designates a 'dark' (also called 'hard' or 'thick') variety of 1 , such as that in the English people, Russian palka, Portuguese mil. - $\mathbf{r}$ is the Italian and Scotch rolled $\mathbf{r}$; $\mathbf{R}$ the uvular $r$ heard in Northumberland and in many parts of France, Germany, etc.; $\check{\mathbf{r}}$ is the Czech 'fricative trill'.

45. $\mathbf{F}, 0$ are lip fricative consonants. $\mathbf{F}$ is the sound we produce in blowing out a candle; it is the Japanese variety of $\mathbf{f}$; $v$ is the Spanish sound of $b$ or $v$ between vowels, as in saber, and one variety of Dutch $w$. - w, the sound of English watch, is formed by narrowing the air passage simultaneously between the lips and in the back of the mouth; $\boldsymbol{M}$ is one variety of Northern English wh. I, the sound of French $u$ in nuit, is formed by narrowing the air passage between the lips and in the front of the mouth. - $\boldsymbol{\theta}$, $\boldsymbol{\gamma}$ stand for the sounds of th in thin, then. I is the untrilled lingual $r$, commonly heard in Southern English in draw, red; the same sign is provisionally made to stand for the Spanish 'soft $r$ ' in pero, which is a mere flap of the tongue. - $\sigma, \rho$ are Bantu sounds; they have tongue position of $\boldsymbol{\theta}, \boldsymbol{\partial}$, combined with strong lip-rounding. $-\boldsymbol{\int}, \mathbf{3}$ are the sounds of show, azure, French $c h, j .-\mathbf{j}$ is the English sound of $y$ in yet; $c$ is the German consonant in $i c h$; it is sometimes 
heard in English words such as hue (hju: or cu:). $\mathbf{x}$ is the sound of $c h$ in the German ach, Scotch loch; $g$ is often heard in North German pronunciation of wagen, regularly in Dutch vlaggen. $\mathbf{x}$ is the deep Arabic $k$ h in Khalifa, often heard as a variety of Swiss German ch and Spanish $j ; \mathbf{b}$ is the Arabic gh, Danish $r$, often heard also as a variety of Parisian $r . \mathbf{f}$ is the voiced $h$ of Arabic, Czech, South African Dutch, etc.; it is sometimes heard in English instead of the ordinary $\mathbf{h}$ between two vowels. - The symbols $\boldsymbol{u}$ and $\mathbf{q}$ may be used for the Arabic hha and 'ain.

46. Vowels. The following are the typical values of the chief rowel symbols:

i the sound of $i$ in machine.

e " " $"$ "French été, Italian bene, German See; also heard in Northern English pronunciation of day, etc.

$\varepsilon \quad " \quad " \quad, \quad$ there(Southern English pronunciation), French fer, Italian cielo.

" " $\quad, \quad$, French patte, frequent also in Scotch pronunciation of pat.

a " " " " father, French pas.

"o "Italian notte, French port.

"o "French côte, Italian come, Northern English pronunciation of home, etc.

$1 " \quad " \quad$ ", Italian uno, English rule.

y $" \quad " u$, French pur, $\ddot{i}$ in German ïber.

ø.,$\quad$ "eu, French peu, $\ddot{o}$ in German hören.

œ " " "cu "French peur, $\ddot{o}$ in German Wörter.

47. $\boldsymbol{x}$ is the Southern English vowel in man; $\boldsymbol{\Lambda}$ is the English vowel in much. I is a sound intermediate between $\mathbf{i}$ and $\mathbf{e} ; \boldsymbol{\sigma}$ is a sound intermediate between $\mathbf{u}$ and $\mathbf{0} ; \mathbf{Y}$ is a sound intermediate between $\mathbf{y}$ and $\boldsymbol{\varnothing}$. $\mathbf{u}$ is a vowel with the tongue position of $\mathbf{u}$ but with lips spread out; it occurs in Gaelic, Japanese, Armenian and Syriac.

48. $\ddot{\mathbf{i}}, \ddot{\mathbf{u}}, \ddot{\mathbf{e}}, \ddot{\mathbf{o}}, \ddot{\varepsilon}, \ddot{\mathrm{o}}$, are mixed (also called 'intermediate' or 'obscure') sounds: $\ddot{i}$ is the vowel in the Russian syn, $\ddot{i}$ that in Norwegian luss.

49. a stands for any obscure vowel of neutral quality, like the first of English again. It is convenient to reserve this sign as far as possible for unstressed vowels. In cases where it is found desirable to distinguish two such vowels, the one with higher tongue position may be written $\boldsymbol{\theta}$ and the one with lower tongue position $\boldsymbol{B}$. 
50. Nasalized vowels are marked thus: $\tilde{\boldsymbol{\alpha}}$ French an, $\tilde{\varepsilon}$ French vowel in pain, $\tilde{\mathbf{1}}$ Portuguese vowel in fim, etc.

51. Quantity, stress, intonation. - Length of any sound is indicated by : placed after the phonetic symbol $\left.{ }^{1}\right)$. Half-length may be marked by : - Stress is marked when necessary, by the sign '; it is recommended that the sign be placed before the stressed syllable ${ }^{2}$ ). Intonation is generally left unmarked. In Swedish and Norwegian texts, however, the sign ${ }^{\mathrm{v}}$ is placed before the stressed syllable of words having the so-called 'compound tone'. No system of signs has yet been definitely adopted for languages such as Chinese in which word-tones are a significant element (see however $\S 85$ and the Chinese and Burmese texts). The Association recommends, however, that the form of such signs should be devised so as to indicate graphically the musical values of the tones.

52. Modifiers. - Various devices make it possible to represent many shades of sounds not included in the alphabet. The following are the most important.

53. The difference between a breathed consonant (such as $\mathbf{s}$ ) and its voiced correspondent (such as z) when not indicated by the shape of the letter, may be marked thus: 1 voiced 1 (the usual sound), I breathed 1 (Welsh $l l$ ). - - Whispered sounds may be marked thus: $\mathbf{u}, \mathbf{i}$.

54 . Inverted consonants (cerebrals), formed by turning up the point of the tongue, may be marked thus: t, $\mathbf{d}, \mathbf{n}, \mathbf{l}, \mathbf{r}, \mathbf{s} ;$ the Arabic emphatics thus: $\mathbf{t}, \mathbf{s}$. etc.; consonants formed with simultaneous glottal closure, thus: p', t', k'. "Assibilated" consonant groups, i. e. groups in which the two elements are so closely connected that the whole might be treated as a single sound, may be represented thus: $\widehat{\mathbf{f} \boldsymbol{j}}, \widehat{\mathrm{dz}}$, or thus: $\mathbf{t} \boldsymbol{\int}$, $\mathbf{d z}$.

55. Palatalized consonants may be represented by means of a dot placed above the symbol of the normal sound (the dot suggesting the connexion with the sounds $\mathbf{i}$ and $\mathbf{j}$ ), thus $\dot{\mathbf{s}}, \dot{\mathbf{i}}, \dot{\mathbf{r}}$. Such sounds occur regularly in Russian and in Irish.

1. The use of a mark over the letter is undesirable on account of the difficulty of combining it with other diacritics such as .

2. From the scientific point of view it would be preferable to put the mark over the symbol of the stressed vowel, but there are practical objections to this plan, e. g. the necessity for cutting a large number of new types, and the desirability of keeping superposed diacritics for indicating shades of sound. 
56. 'Tense' and 'lax' vowels may be distinguished respectively by acute and grave accents. Thus the English sit might be written sit $^{1}$ ) to distinguish it from the French site (sít).

57. + after any letter means tongue slightly raised. T means tongue slightly lowered. ) means lips more rounded; ( means lips more spread.

58. A syllabic consonant may be marked thus $\mathbf{n}$; the consonantal element of a diphthong may be marked thus $\breve{\text { u. }}$

59. Finally, some shades of sound may be marked by placing a small letter as index to a large one: thus $\int^{\mathrm{s}}$ means a variety of $\int$ rather resembling $\mathbf{s}$.

\section{'NARROW' AND 'BROAD' TRANSCRIPTION}

60. The style of transcription used in any particular case depends to some extent on the object in view. In works of a scientific character in which it is desired to have separate symbols for all the shades of sound existing in several languages, a very large number of symbols and diacritical marks may be necessary (with the result that the transcription of any one of the languages becomes complicated and difficult to read). Transcriptions of this kind are called narrow transcriptions.

61. When, however, the object is rather to deal chiefly with one language and that too from a strictly practical point of view, it is desirable that the form of transcription should be simple and should have as few diacritical marks as possible. Such a style of transcription is called a broad transcription.

62. A broad transcription may be more accurately defined as a transcription obtained by using the minimum number of symbols requisite for representing without ambiguity the sounds of one language independently of other languages.

63. The necessity for the use of broad forms of transcription in practical work becomes evident when we consider the enormous number of minute shades of sound in existence. If we compare any two languages, the number of sounds which are absolutely identical in each is extremely small. Take the case of such a simple sound as $\mathbf{p}$. The English $\mathbf{p}$ in pat in distinguished from the French $\mathbf{p}$ in patte by the presence of a certain 'aspiration';

1. The vowel might also be written $I$ in accordance with the $6^{\text {th }}$ Principle (e), p. 17. 
yet it would be highly inconvenient in practical work to have to . indicate this aspiration everywhere by writing $\mathbf{p}^{2}$ in English transcriptions ${ }^{1}$ ).

64. Similarly in an ordinary practical phonetic script (as distinguished from a more detailed form of script suited for scientific purposes) it is unnecessary to have separate symbols for the French vowels in note (not) and porte (port) (the latter of which is slightly lower than the former) because it is the regular rule that $\mathbf{r}$ has a lowering effect on preceding vowels in French. Again, in ordinary practical phonetic script it is not usually necessary to use two symbols for the two varieties of 1 heard in the most usual pronunciation of the word little, because we know once for all that the 'clearer' variety is regularly used before vowels and the 'darker' variety before consonants and finally.

65. The general rule for strictly practical phonetic transcription is therefore to leave out everything that is self-evident, and everything that can be explained once for all. In transcribing any given language it is in general sufficient to represent the distinctive sounds only; for each distinctive sound the typical international symbol should be chosen; and, if necessary, the exact shades of sound used either throughout or in certain positions may be explained (with the use of modifiers) in an introductory note.

66. In scientific work a more elaborate form of script is often necessary. The extent to which the use of modifiers should be resorted to depends, however, on circumstances. In some cases it may be useful to adopt a compromise between a narrow and a broad notation. Thus a teacher of English in France may find it desirable to mark the English vowels in fit, put with the grave accent (fit, pìt) in order to remind his pupils continually of the characteristic quality of these sounds; a teacher of French in England might often with advantage write pœpl in order that his pupils may be less liable to pronounce the final $\mathbf{1}$ in peuple like that in the English word people pi:pl.

67. These are points on which each person must use his own discretion. They do not in any way affect the general principle referred to above $(\$ 65)$.

1. This must, however, be done in such languages as Syriac and Chinese, where the aspirated and unaspirated $\mathbf{p}$ are distinctive sounds. 


\section{PRINCIPLES OF TRANSCRIPTION FOR LANGUAGES HITHERTO NOT TRANSCRIBED}

68. We give here a summary of some of the more important principles of transcription for the guidance of missionaries and others wishing to record the pronunciation of languages hitherto not transcribed.

69. $1^{\text {st }}$ Principle. In settling for any language the form of transcription best suited for practical purposes (as distinguished from scientific purposes), the language should be regarded by itself without reference to other languages.

70. $2^{\text {nd }}$ Principle. It is necessary to ascertain what are the distinctive sounds in the language, $i$. e. those which if confused might conceivably alter the meanings of words. Shades of sound which are occasioned by proximity to other sounds, absence of stress and the like, very often do not require special symbols. For examples see $\S 64$.

71. $3^{\text {rd }}$ Principle. Typical single sounds should be represented (as far as possible) by single letters without diacritical marks. Diacritics should (as far as possible) only be resorted to for the purpose of representing shades or varieties of the typical sounds.

72. $4^{\text {th }}$ Principle. The rowel letters a, $\mathbf{e}, \mathbf{i}, \mathbf{0}, \mathbf{u}$, should be taken to have their Italian values, i. e., roughly speaking, the values which they have in the English words calm, get, machine, note, rule.

73. $5^{\text {th }}$ Principle. If the language does not contain more than - one variety of each of the sounds $\mathbf{e}, \mathbf{i}, \mathbf{0}, \mathbf{u}$, these symbols should be used for the varieties occurring. If the language contains one sound of the type a, not being a distinctly 'back' variety, the symbol a should be used. If the language contains a sound of the type of French $u$ it should be represented by $\mathbf{y}$; if it contains one sound of the type of French $e u$, not being a distinctly 'close' variety, it should be represented by $\propto$.

74. $6^{\text {th }}$ Principle. (a) If the language contains two distinctive varieties of $e$, the variety with higher tongue position should be represented by $e$ and the variety with lower tongue position should be represented by $\varepsilon$. Such are the French sounds of $e$ (e) and $\grave{e}(\boldsymbol{\varepsilon})$.

(b) If the language contains two distinctive varieties of $\mathbf{0}$, the variety with higher tongue position should be represented by 0 and the variety with lower tongue position by o. Such a pair is found in the English words note (o), not (o). Another 
(slightly different) pair of the same kind is found in the French words tôt (o), tort (o).

(c) If the language contains two distinctive varieties of a, the variety with tongue further back should be represented by $\boldsymbol{\alpha}$ and the variety with tongue further forward by a. Such are the French sounds in pas (a) and page (a).

(d) If the language contains two distinctive varieties of $x$, the variety with higher tongue position should be represented by $\varnothing$ and the variety with lower tongue position by $\infty$ Such a pair is found in the French words peu (ø), peur (œ).

(e) If the language contains two distinctive varieties of $\mathbf{i}$ or $\mathrm{I}$, the varieties with higher tongue position may be represented by i, II and those with lower tongue position by $\mathbf{I}, \mathbf{U}$.

75. rth Principle. If the language contains sounds which to an untrained ear sound like the groups kj (as in cube kju:b), $\mathbf{g j}$, nj (as in onion), lj (as in million), but are felt by natives to be single sounds and not compounds, the appropriate symbols are generally $\mathbf{c}, \mathbf{J}, \mathbf{j}, \boldsymbol{\Lambda}$, respectively.

76. $8^{\text {th }}$ Principle. When vowels of similar though distinct quality are connected by the relation that one is always longer than the other under similar circumstances (i. e. when surrounded by the same sounds and pronounced with the same degree of stress), a simplification of the phonetic transcription may sometimes be effected by using only one symbol with or without a length-mark. Thus many transcribers of English write the vowels in feet and fit as $\mathbf{i}$ : and $\mathbf{i}$ respectively, instead of writing $\mathbf{i}$ and $\mathbf{I}$ according to the $6^{\text {th }}$ Principle (e). (It will be observed that the first of these vowels is always longer than the second under similar circumstances, e. g. the vowel in feet is longer than that in fit, the vowel in heed is longer than that in hid, the second vowel in linseed is longer than that in acid).

\section{FURTHER DEVELOPMENTS}

77. Completeness and perfection are ideals unattainable in this world, and the International Phonetic Alphabet lays no claim to either. It is freely admitted that some of the symbols might be improved; and it is evident that it may also be necessary to invent new signs either for newly discovered sounds or to distinguish shades of sound hitherto left undistinguished. Improvements are continually suggested by members of the Association and discussed in the Maître Phonétique; but none are definitely adopted 
without careful consideration and the vote of a majority of the Council.

78. Among the suggestions lately made we may mention the following:

79. $\mathbf{p}^{e}, \mathbf{t}^{\mathbf{e}}$, etc. are suggested for the aspirated $\mathbf{p}, \mathbf{t}$, etc. (see $\S 63$, note).

80. $\mathbf{p}_{1}, \mathbf{t}_{1}, \mathbf{k}_{1}$, etc. have been suggested for final $\mathbf{p}, \mathbf{t}, \mathbf{k}$ pronounced without explosion (as in Chinese, Burmese etc.). have been suggested as general symbols denoting any consonant or vowel respectively. $\boldsymbol{\pi}$ and $\boldsymbol{\beta}$ have been suggested for the lipteeth plosive consonants.

81. For $\varnothing$ and $\boldsymbol{\infty}$ some would prefer to write $\boldsymbol{\theta}$ and $\boldsymbol{0}$. The type $I$ is generally considered unsatisfactory, as also is the mark of length :; but none of the alternatives hitherto proposed seem any better.

82. Many members think that a special sign (n or o or 9?) ought to be devised for the very low Southern English vowel in not as distinct from the open Italian $o$.

83. $\mathbf{r}$ has been suggested for the variety of $\mathbf{r}$ formed by a single flap of the tip of the tongue. Some consider that separate

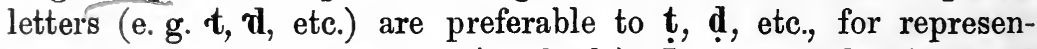
ting the inverted consonants (cerebrals). It appears that it would be desirable to admit an alternative mode of representing the Russian palatalized consonants for use by printers not possessing the types $\dot{\mathbf{s}}, \dot{\mathbf{n}}$, etc. (e. g. $\mathbf{s}^{\prime}, \mathbf{n}^{\prime}$, etc.). Many writers urge the advisability of adopting single symbols for the 'assibilated' groups $\widehat{\mathbf{t} \int}, \widehat{\mathrm{ts}}$, etc. It may also be necessary to distinguish by special letters the breathed $\mathbf{1}, \underset{0}{\mathbf{r}}, \mathbf{m}, \mathbf{n}, \mathfrak{\mathbf { n }}, \dot{\mathbf{y}}$, occurring in Welsh, Icelandic, Bantu languages, etc. $(\mathbf{\Phi}, \mathbf{z}, \mathbf{m}, \mathbf{n}, \mathbf{h}, \mathbf{b}$, have been suggested for this purpose).

84. Some are of opinion that it might be useful for some purposes (such as transliteration of Indian languages) to have some special symbols for long vowels. $\mathbf{\alpha}, \mathbf{e}, \mathbf{i}, \boldsymbol{\sigma}, \mathbf{u}$ have been suggested for this purpose.

85. The signs " - , - have been suggested for the six tones of Cantonese, and $-^{\prime}-^{\prime \prime}$ have been suggested for the four tones of the Mandarin language, these signs being indicative of the musical values of the tones. 


\section{SPECIMENS}

86. In illustration of the above mentioned principles of transcription, we now give some specimens of phonetic transcription. The texts are versions of the well known fable of the North Wind and the Sun' in various languages ${ }^{1}$ ).

87. It may well be that a reader, on examining the pronunciation here given of his own language, may find some forms which do not correspond with his own pronunciation. This arises partly from the fact that no two persons pronounce exactly in the same way, and partly from the fact that the same person will often pronounce a word differently under different circumstances. Phonetic writing reproduces such differences, and therefore a text which reproduces exactly the pronunciation of one person does not necessarily correspond exactly with that of another. We have endeavoured as far as possible to indicate the average pronunciation of educated persons in each case. The reader will do well to note the points in which his pronunciation differs from that indicated in the specimens.

\section{TEXT}

The North Wind and the Sun were disputing which was the stronger, when a traveller came along wrapped in a warm cloak. They agreed that the one who first made the traveller take off his cloak should be considered stronger than the other. Then the North Wind blew with all his might, but the more he blew, the more closely did the traveller fold his cloak around him; and at last the North Wind gave up the attempt. Then the Sun shone out warmly, and immediately the traveller took off his cloak; and so the North Wind was obliged to confess that the Sun was the stronger of the two.

\section{SOUTHERN ENGLISH}

[When not otherwise marked the stress is on the first syllable of the most important words. - Two consecutive vowels form a diphthong, the second element being the consonantal element. -

1. The Editors will be pleased to receive versions of this fable in languages or dialects not included here, for publication either in subsequent editions of this pamphlet or in the Maître Phonétique. 
$\mathbf{i}, \mathbf{u}, \boldsymbol{\partial}, \boldsymbol{\theta}$ without length-marks are lax. $-\mathbf{i}$ in unstressed syllables $=\mathbf{i}+$. $\mathbf{i}$ :, n: are often diphthongized (ij, $\mathbf{n w}$ ) especially when final. - Short $\boldsymbol{\partial}$ is very open when final $(=\boldsymbol{v})$; $\boldsymbol{\theta}$ : stands for $\ddot{\text { E. }}$

$\mathbf{t}, \mathbf{d}, \mathbf{n}, \mathbf{l}$ are formed with the tip of the tongue against the teeth-ridge (gums). $-\mathbf{r}$ is generally fricative $(=\mathbf{x})$, though some speakers use a single flap of the tongue when intervocalic. A 'dark' variety of $\mathbf{l}(\mathbf{t})$ is used finally and before consonants. Initial $\mathbf{p}, \mathbf{t}, \mathbf{k}$ are slightly aspirated.

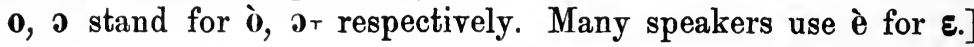

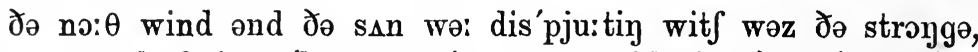

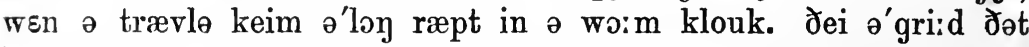
də wan hu: fa:st meid də trævlə teik o:f (h)iz klouk fud bi

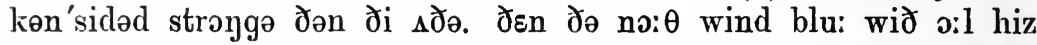
mait, bət $\partial_{\theta}$ mo: hi: blu:, $\partial_{\theta}$ mo: klousli did $\partial_{\theta}$ trævle fould

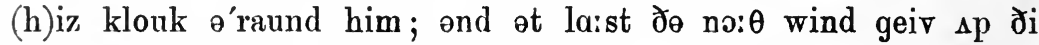

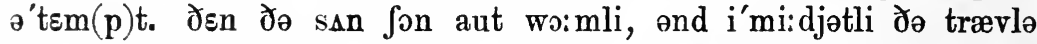
tuk o:f (h)iz klouk; ənd sou də no: $\theta$ wind wəz $\theta^{\prime}$ blaidzd to

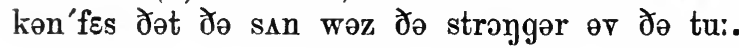

Examples of combinations of sounds not occurring in the above:-cheer tfiə, fairness feənis, poor puə, nature neitfe.

For some purposes (e. g. in books dealing with Scottish pronunciation) it appears desirable to have a form of phonetic spelling of Southern English independent of the length mark :. The following form is suggested for such cases.

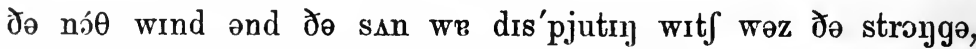

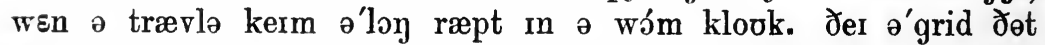

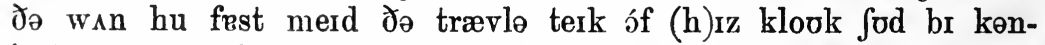

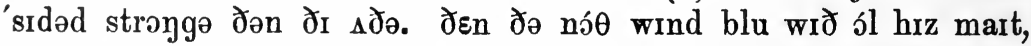

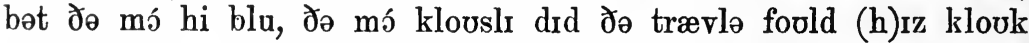

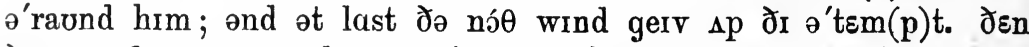

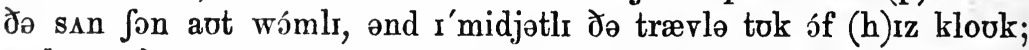

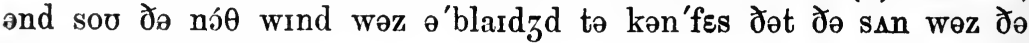
stroyger $ә \nabla$ $\partial \partial$ tu.

The additional words at the end of the preceding version

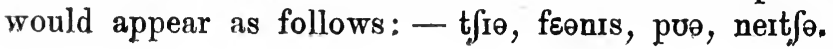




\section{NORTHERN ENGLISH}

[Stress and sound values as in Southern English with the following exceptions. e:, o: are tense and only slightly diphthongized. - $\mathbf{r}$ is slightly trilled. $\boldsymbol{x}$ is very weak and often loses its consonantal character, producing merely an 'inverted' (cerebral) modification of the preceding vowel.]

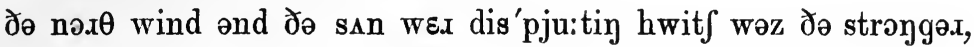

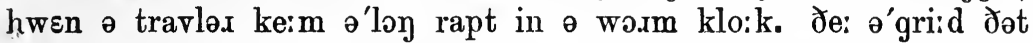

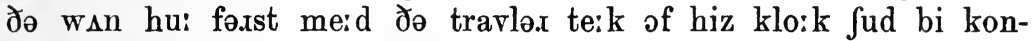

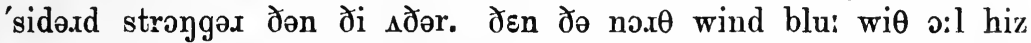

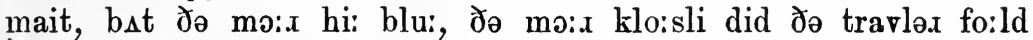

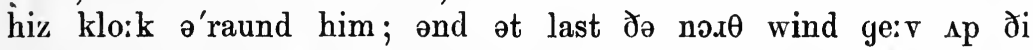

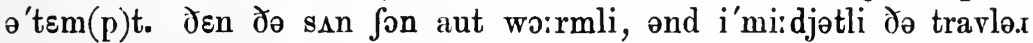
tuk of hiz klo:k; ənd so: $\partial ә$ nəx $\theta$ wind wəz o'blaidzd tu kon'fes

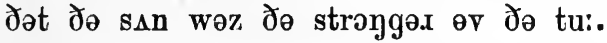

The additional words would appear as follows:- - t fi:ər, fe:ə.nnəs, pu: өr, ne: tjə..

\section{SCOTCH PRONUNCIATION}

[Stress and sound values as in Southern English with the following exceptions. - Length may be significant; thus the i in agreed is long while that in deed is short. Tense and lax $\mathbf{i}$ must therefore have separate symbols ( $\mathbf{i}$ and $\mathbf{~})$. Tense and lax $\mathbf{a}$ are distinguished as $\boldsymbol{\zeta ,}, \boldsymbol{\partial}, \mathbf{n}$ is alway's tense. $\boldsymbol{O}$ is as in French (higher than in Southern English). $\mathbf{I}=\mathbf{\mathbf { I }} r$. e, $\mathbf{0}$ are tense and not diphthongized. - aI often becomes əI when not followed by $\mathbf{v}, \mathbf{z}, \boldsymbol{\partial}$ or $\mathbf{r}$. - $\mathbf{r}$ is normally trilled, but is often reduced to a single flap of the tongue or to the fricative I when final or followed by a consonant.]

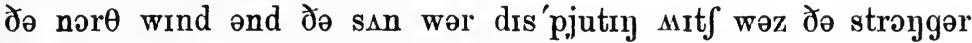

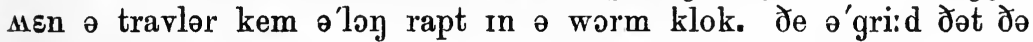
wan hu fərst med də travlər tek of hiz klok fud br kən'sidərd

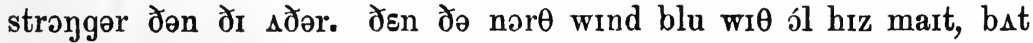

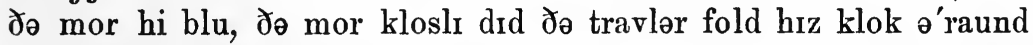

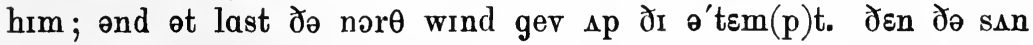
fon aut wormlı, ənd I'midjetlı $\partial_{\partial}$ travlər tuk of hiz klok; ənd so

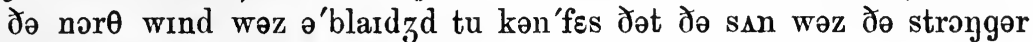
әे ठə tu.

The additional words would appear as follows:-t $\int \mathrm{ir}$, fernis, pur, netjər. 


\section{AMERICAN FNGLISH}

(Typical pronunciation for New York State and the central portion of the United States)

[Stress and sound values as in British English with the following exceptions. I stands for $\mathbf{I}$; when final or followed by a consonant it causes considerable 'inverted' (cerebral) modification of the preceding vowel. Vowels are generally slightly nasalized when they stand next to nasal consonants.]

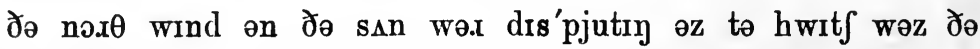
st.ə:ygist, hwen ə txævələx ke:m ələ:y, xæpt in ə woxm klouk.

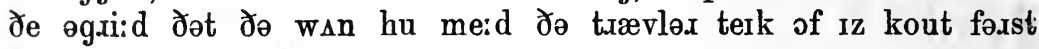

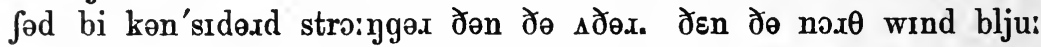

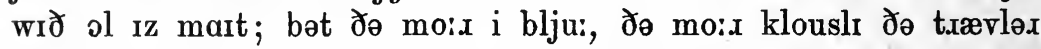

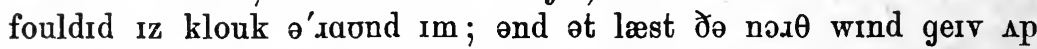

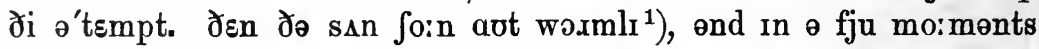

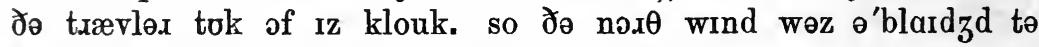

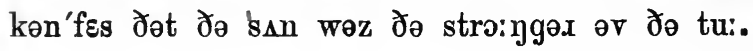

\section{FRENCH (Northern)}

[Stress is generally on the last syllable of important words (on the last but one, if the vowel of the last is $\theta$ ). - Two consecutive vowels do not form a diphthong. - Initial and final voiced plosives and fricatives are fully voiced. - Initial $\mathbf{p}, \mathbf{t}, \mathbf{k}$ are unaspirated. $\mathbf{t}, \mathbf{d}, \mathbf{n}, \mathbf{l}$ are dental. - $\mathbf{r}$ may be $\mathbf{r}$ or $\mathbf{R}$ (or even $B$ in Parisian speech).

u, $\boldsymbol{\rho}$ are somewhat advanced from the back position. $\tilde{\varepsilon}, \tilde{\boldsymbol{e}}, \tilde{\mathbf{\rho}}$ stand for $\tilde{\varepsilon}_{\tau}, \tilde{\boldsymbol{o}}_{\tau}, \tilde{\mathbf{\jmath}}_{\perp}$. $\tilde{\mathbf{\jmath}}$ might also be written $\left.\tilde{\mathbf{o}}_{\text {.] }}\right]$

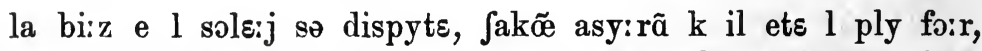

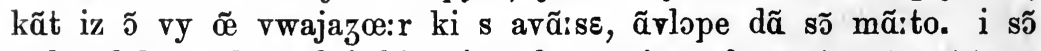

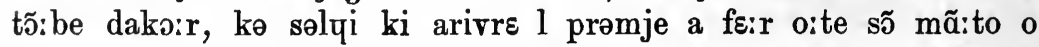
vwajazœ:r, søre rgarde $\mathrm{kom}$ lo ply fo:r. alo:r la bi:z $\mathrm{s} \varepsilon \mathrm{mi}$ a sufle d tut sa fors; me ply el sufle, ply l vwajazœ:r se:re sõ

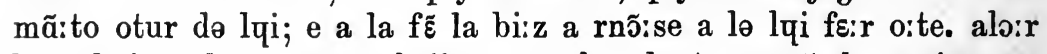
lo sole:j a komã:se a brije, e o bu d $\tilde{\text { œ }}$ momã l vwajazœ:r,

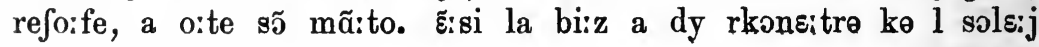
ete 1 ply fo:r de dø. 


\section{GERMAN (North)}

[Stress as in English. - Initial p, t, $\mathbf{k}$ are aspirated. - Two consecutive rowels form a diphthong, the second element being the consonantal element. - Short $\mathbf{i}, \mathbf{u}$ are lax and might be written I, $\boldsymbol{J} . \boldsymbol{\alpha}$ is somewhat advanced from the back position. $\varepsilon, \boldsymbol{\partial}, \boldsymbol{\theta}$ stand for $\varepsilon_{\llcorner}, \boldsymbol{\partial}_{\perp}$, $\ddot{\mathbf{e}}$; they are somewhat lowered before $\mathbf{r}$. $\int$ is accompanied by lip-rounding. $\mathbf{r}$ is $\mathbf{r}$ or $\mathbf{R}$; it is weak when final or followed by a consonant.]

'ainst Stritən ziç nortvint 'unt zonə, ve:r fon 'i:nən baidən vo:1 der Jterkərə ve:re, 'als. 'ain vandərər, dər 'in 'ainen varmən mantəl gə'hylt vair, dəs ve:gəs da'he:r ka:m. zi: vurdən 'ainiç, das de:rje:nigə fy:r dən Sterkərən geltən zoltə, der dən vandərər tsvinən vy:rdə, zainən mantəl 'aptsu: ne:mən. dər nortvint bli:s mit 'alər maxt, 'abər je' me:r 'ยr bliss, desto' fester hyltə ziç dər vanderər 'in zainən mantəl 'ain. 'Entliç ga:p der nortvint den kampf 'auf. nu:n 'Er'vermtə di zonə di luft mit 'i:rən froyntliçən ftra:lən 'unt fo:n na'x ve:nigən 'augənblikən tso: $\mathrm{k}^{1}$ ) dər vandərər zainən mantəl 'aus. da muste dər nortvint tsu:ge:bən, das di' zonə fon 'i:nən baiden dər fterkere va:r.

\section{ITALIAN (Stage pronunciation)}

[Stress falls on the penultimate syllable of the important words, except where otherwise marked. - Initial $\mathbf{p}, \mathbf{t}, \mathbf{k}$ are not aspirated. - t, $\mathbf{d}, \mathbf{n}, \mathbf{l}$ are dental; $\mathbf{r}$ is strongly rolled. - t $\mathbf{f}$; $\mathbf{d z}$ are rather more palatal than in English. - $\mathbf{m}$ is lip-teeth when followed by $\mathbf{f}$ or $\mathbf{v}$. $-\boldsymbol{a}$ is somewhat advanced from the back position.]

si bistittfa:vano un dzorno il vento di tramonta:na e il so:le, 1 u:no pretendendo d esser pju fforte dell altro, kwando vi:dero um viaddzato:re, ke vreni:va innantsi, arvolto nel mantello. i duĕ litiganti kom'vennero allo:ra, ke ssarsbbe ritenu: to pju fforte, ki ffosse riuffiito a ffar si, ke il viaddzato:re si to $\Lambda$ Cesse il mantello di dosso. il vento di tramonta:na komin't $\int$ a a ssoffja:re kom violentsa, ma pju ssoffja:va, pju il viadd $z^{a}$ to:re si strindze: va nel mantello; tanto ke alla fi:ne il pa:vero vento dovette de'sistere

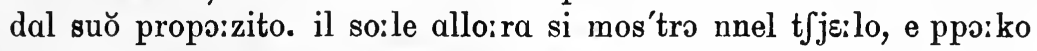
do: po il viaddzato:re, ke ssenti:va kaldo, si tolse il mantello. e lla

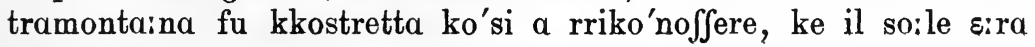
pju fforte di le: ̌̆. 


\section{SPANISH}

[Stress as in Italian. - Two consecutive vowels generally form a diphthong. $-\mathbf{r}$ is strongly rolled; $\boldsymbol{x}$ is a single flap of the tip of the tongue. $\mathbf{S}$ is a retracted variety, and $\boldsymbol{\theta}$ stands for $\boldsymbol{\theta}^{\boldsymbol{s}}$. (In America $\boldsymbol{\theta}$ is replaced by $\mathbf{s}, \mathbf{r}$ often by fricative $\boldsymbol{x}$, and $\boldsymbol{\mathcal { C }}$ often by $\mathbf{j}$ ). $\mathbf{e}, \mathbf{a}, \mathbf{0}$ are intermediate between the French $\mathbf{e}$ and $\varepsilon, \mathbf{a}$ and $\mathbf{\alpha}, \mathbf{0}$ and $\boldsymbol{\rho}$ respectively. $\boldsymbol{v}, \boldsymbol{\partial}, \boldsymbol{q}$ are pronounced without much friction. $\mathbf{b}$ and $\mathbf{g}$ are loosely stopped. - $\mathbf{m}$ is lipteeth when followed by $\mathbf{f}$.]

disputavan el $\theta$ rer $\theta 0$ j el sol, porfiando kaða kŭal en $k$ el tenia mas fŭer $\theta a$, kŭando de pronto, ben $\left\langle\mathrm{e}^{\prime}\right.$ gax um b̆axe.ro emboӨað̆ en una gray kapa. kombinı̌exon ey ke kien antes axia ke 1 vĭaxexo se kitase la kapa keðaxia por mas fŭerte. el $\theta$ ĭer $\theta 0$ se ponĕ a so'plar de firme; pexo kŭanto mas soplava, mas el

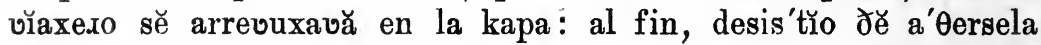
ki'tar. enton $\theta e s$, el sol em'p̌e $\theta$ a rresplande' $\theta e r, j$ al kavo дӗ um momento, el viaxexo šente ka'lox i se kita la kapa. a'si, el

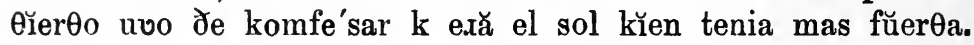

\section{PORTUGUESE}

[Stress as in Italian. - $\boldsymbol{v}, \boldsymbol{\partial}, \boldsymbol{g}$ are pronounced without much friction. - $\mathbf{I}$ is a single flap of the tongue. $-\boldsymbol{J}, \mathbf{Z}$ are retracted varieties. - A 'dark' variety of $\mathbf{l}(\mathbf{t})$ is used finally and before consonants. - $\boldsymbol{\alpha}$ is slightly advanced from the back position, except when followed by $\mathbf{l}(\mathbf{t})$. $\boldsymbol{v}=$ the first vowel in the English about. $\boldsymbol{\theta}$ stands for $\grave{\mathbf{i}}$. $-\mathbf{i}, \mathbf{u}$ frequently lose their voice when unstressed.]

kõnten'diěŭ u sol i u vẽntu, $\bullet$ ved kwal tigre maif forse,

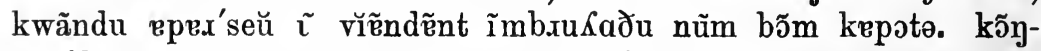

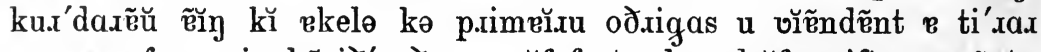
u rggzaরu səxie kə̃sið'xað u mă̌ forte duz doŭf. niftu u vẽntu

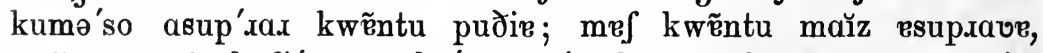

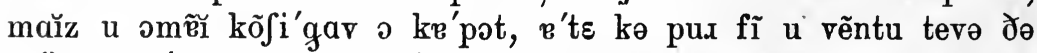

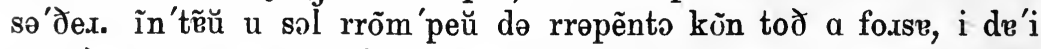
a nað̌ u vĩẽndẽntə ti'xav o kepote, plu'ke u vẽntu fi'ko ssvẽndu k̆ u sol pudir mă̌ ki elə.

\section{CATAIANIAN}

[Stress as in Italian. - . I formed by a single flap of the tip of the tongue. - $\$$ is as in English people. - a as in English father; $\boldsymbol{\theta}$ as in the first syllable of about, $\boldsymbol{x}$ somewhat lower 
than this; I, $\mathbf{J}$ stand for lax i, u. - $\mathbf{m}$ is lip-teeth when followed by $\mathbf{f}$.]

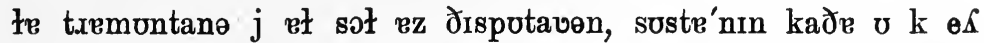
e.rध ł mes fort, kŏan dp soptə, bewən om bred'dze kr s $r^{\prime}$ kost rmbułr'kat en one gray kape. ban kombe'ni ke $ł$ ki par'me fexi ke $\nsucceq$ vied'dze s txe'qez łe kape sexi tiy'got pe $ł$ mes

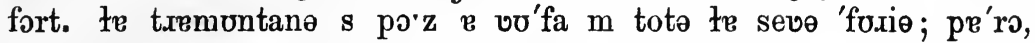

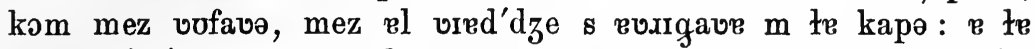

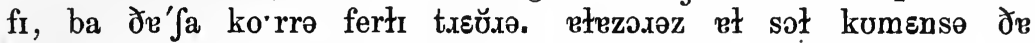

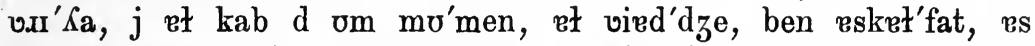

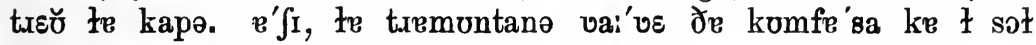
exe $¥$ mes fort.

\section{WELSH (North)}

[Stress is on the last syllable but one of every important word. $i$ is slightly advanced from the standard 'mixed' position.]

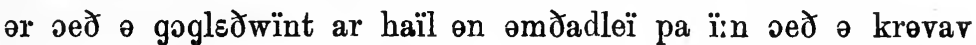

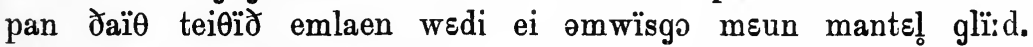

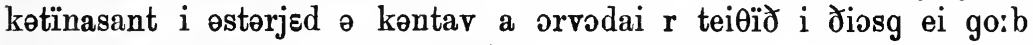

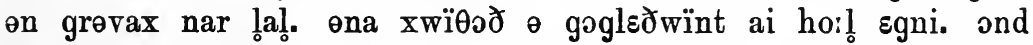

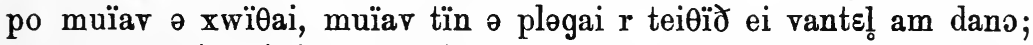

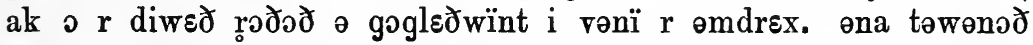

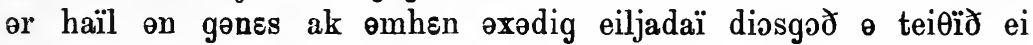

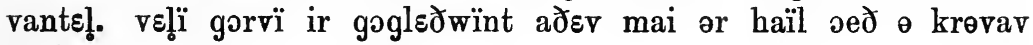
or daï.

SWEDISH (Stockholm colloquial)

$[\mathbf{p}, \mathbf{t}, \mathbf{k}$ are unaspirated when intervocalic, also when preceded by $\mathbf{s}$; they are aspirated initially when stressed. - $\mathbf{d}$ is an 'inverted' d. - o: has considerable lip-rounding. - $\mathbf{0}$ :, y:, $\ddot{0}$ are used to represent the vowels in sol, hus, upp; $\mathbf{0}=\mathbf{0}$ ), $\mathbf{Y}=\boldsymbol{\emptyset}$ ), and both are more or less diphthongized.

$\checkmark$ is prefixed to words having the so-called 'compound' tone.]

y gon so vgre:la vno:dan'vindn o 'su:ln mə va'ran: om 'vem: sm $\mathrm{va}^{\cdot}$ 'starkast. 'ret: som do 'va:, kom ən man' po 'lan:sve:gən. han hado $n$ 'var:m 'kap:a 'po: sei. vno: dan o 'sv:ln kom øvr'ens a 'den: va dn 'starkastə, som köndə fo 'o: honəm 'kap:an.

`no:ḍan'vindn bœrja vblo:sa o val:a 'krafter, mən jö v vær: jik 'po:, jö vte:tarə dro:g 'man:n vapian om sei. o to 'sly:t ga: vnv: dan'vindp op 'stri:dn. o ve:dan tit:a 'sv:lən 'fram: o vbœrja vgasia. o nx: varøide de into len: $ә$ vin:an 'man:n toig 'o: sei vap:an. do fik 'no:ḍan'vindn 'lo: sm va dn vstar: kasto. 


\section{RUSSIAN (St. Petersburg pronunciation)}

[To avoid numerous long explanations, certain non-significant shades of sound have been distinguished in the following transcript. - Unstressed vowels are generally extremely short, lax and obscure in quality.

$\boldsymbol{a}$ is an advanced variety. $\mathbf{u}, \boldsymbol{\jmath}, \boldsymbol{\theta}$ stand for $\mathbf{u}_{\tau}, \boldsymbol{\partial} \boldsymbol{\tau}_{\boldsymbol{c}}, \dot{\mathbf{e}} . \ddot{\mathbf{i}}=\mathbf{a n}$ advanced $\mathbf{u r}$. $\mathbf{i}$ is not very tense. $\theta$ and $\mathbf{I}$ are very short obscure vowels, the first being nearer to $\ddot{i}$ and the second nearer to $\mathbf{i}$. $\mathbf{Y}$ is $\mathbf{I}$ with slight lip-rounding added. $\ddot{\boldsymbol{\sigma}}$ is $\boldsymbol{\theta}$ with slight liprounding added. $\boldsymbol{\Lambda}$ is equivalent to $\boldsymbol{O}$ without lip-rounding.

Before palatalized consonants the vowels $\mathbf{\alpha}$, $\mathbf{i}$ are somewhat advanced, and $\mathbf{e}, \mathbf{i}$ are somewhat raised.]

$\Delta d$ 'nazdə, 'se

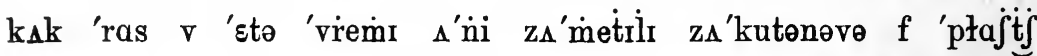

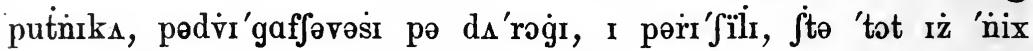

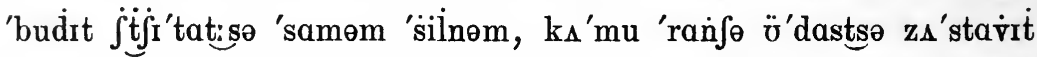
'putniks 'snat 'płajtf. 'tut 'sevirner 'vetrr prinil'sa 'dut izs 'fsex 'sił; nə 't

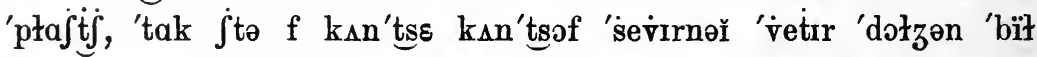

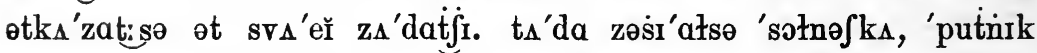

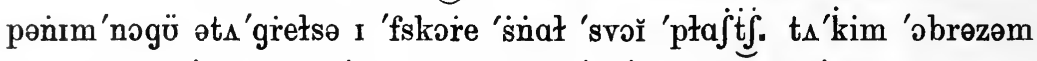

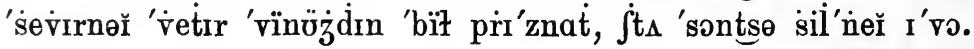

\section{POLISH}

[ $t$ is similar to the English 1 in people; with some speakers, however, the articulation of the tip of the tongue is dropped, the sound then becoming a kind of w. - In s, $\mathbf{z}$ the 'front' of the tongue is raised as for $\mathbf{c}, \mathbf{j}$ and the tip is simultaneously raised close to the upper teeth.]

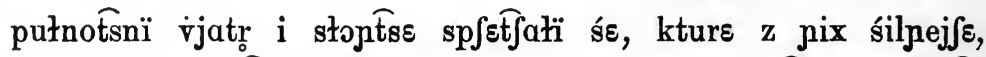

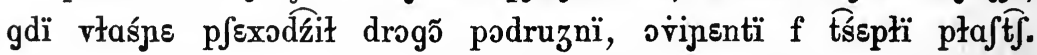

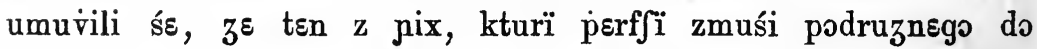

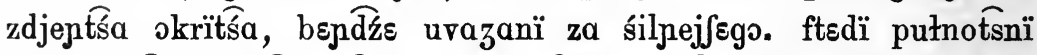

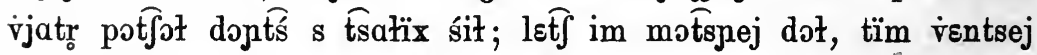

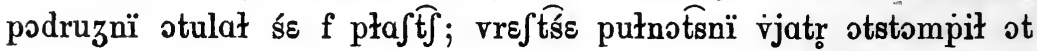




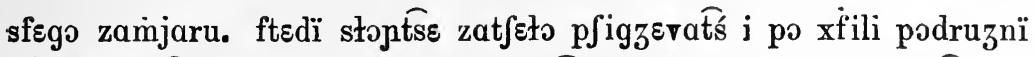
zdjoł okrïtśe. f ten sposup pułnotsnï vjatro muśał p pïznatśs, $z^{\varepsilon}$ słontse bïło śilnejfe odjnego.

\section{CZECH (of Bohemia)}

[ $\check{\mathbf{r}}$ is a rolled $\mathbf{r}$ pronounced with strong simultaneous friction.]

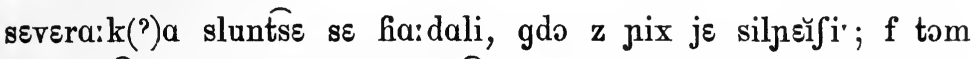

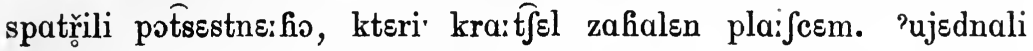

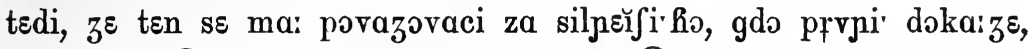

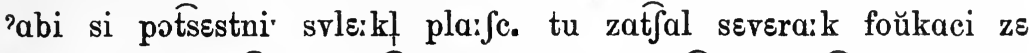

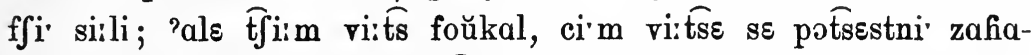

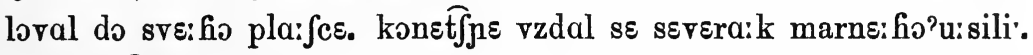
pak zatfalo sluyko svi:cit(?)a hřa:t, 'a za nejaki (?)okamzik

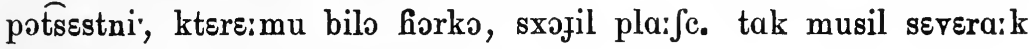

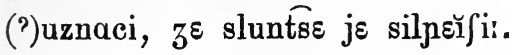

\section{HUNGARIAN}

[The stress is on the first syllable of every important word. $\mathbf{p}, \mathbf{t}, \mathbf{k}$ are unaspirated, as in French. - $\mathbf{r}$ is strongly rolled; $\boldsymbol{v}$ has very little friction; $\mathbf{t}, \mathbf{d}, \mathbf{n}, \mathbf{l}$ are dental. - Stressed $\varepsilon$ is very near to the English $\mathfrak{x}$ in man; unstressed $\varepsilon$ has a somewhat higher tongue position than stressed $\varepsilon$. $\mathbf{a}$ is very much retracted and is practically indistinguishable from the English vowel in not.]

az e:saki se:l najban vitatkozot a nappal, hoł kettsjyk kœzyl mejik az $\varepsilon r \varnothing: \int \varepsilon b$ midø:n $\varepsilon$ utaft la:ttak, kaba:ca:ba burkolo:dzva

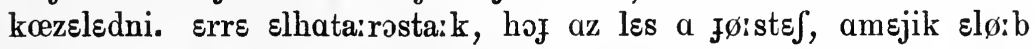

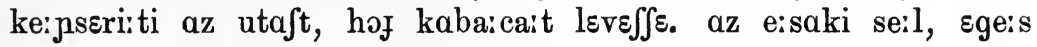

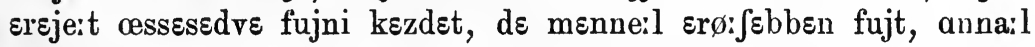
sorगfabra vonta œesse kabaica:t az utaf, miig ve:gre az eisaki

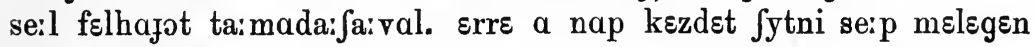

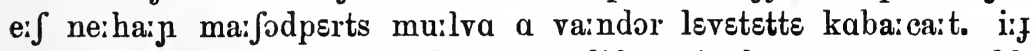

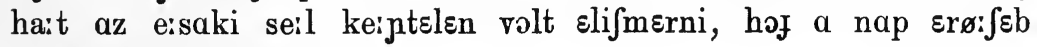
na:la:na:l.

\section{FINNISH}

[The stress is on the first syllable of all important words. In the diphthongs (even in uo and ie) the second element is the weaker. $\mathbf{p}, \mathbf{t}, \mathbf{k}$ are unaspirated as in French. $\mathbf{v}, \mathbf{j}$ are pronounced 
without much friction. Before a pause final -n is very weak. In groups of two consonants, the second (if not doubled) is extremely short.

- $\mathbf{e}$ is $\boldsymbol{\theta}_{\tau} ; \mathbf{i}$ is $\mathbf{i}_{\tau}$, the lowering being particularly noticeable in the diphthongs ai, ei, etc.; many speakers use a lowered $\mathbf{u}$ and $\mathbf{y}$ in the diphthongs a1, ay, etc.; $\mathbf{a}$ is a kind of advanced $\mathbf{a}_{\perp}$ or retracted $\mathfrak{x}_{\tau} ; \mathbf{0}$ is $\mathbf{o r}_{\tau} ; \emptyset$ is $\boldsymbol{\emptyset}_{\tau} ; \mathbf{y}$ is $\mathbf{y}_{\text {เ.] }}$ ]

pohjatu:li ja aurinko vaittelivat, kummalla olisi enempi voima: kun samalla nakivat 'kulkian, jolla oli ylla:n lanmin vaippa. silloin sovitti:n, etta 'se on vakevampi, joka 'pikemmin sa: kulkialta pa:llysva:tte:m pois. nytkøs pohjatu:li puhaltama:n ni(:)n etta 'viuhui; mutta mita kovempa: se puhalsi, sita 'tarkemmin ka:ri vaim mies vaippa: ymparille:n; ja vi:mein tu:li heittikin koko homman sikse:n. silloin alkoi aurijko lampimasti lloista:, eika aika:ka:n, ni(:)y kulkia ri:sui vaippansa. 'ni:n oli tu:lem pakko myønta:, etta auriyko oli kun 'olikin vakevampi.

\section{SOUTH AFRICAN DUTCH}

[Stress is on the first syllable of important words, when not otherwise marked. - Two consecutive vowels form a diphthong the second element being the consonantal element. $-\mathbf{e}=\mathbf{e}_{\perp} ; \mathbf{0}=\mathbf{0}$, except in the diphthongs $\mathbf{\theta i}, \mathbf{o u}$, where the $\theta$ is somewhat retracted, and the $\mathbf{0}$ somewhat advanced; $\boldsymbol{\theta}=\grave{\ddot{\mathbf{e}}}_{\perp}, \boldsymbol{\boldsymbol { e }}=\grave{\mathbf{0}}_{\perp} ; \mathbf{h}=\mathbf{h}$.]

di no:rdevənt ən di son vas an $t$ strei vi fã hœlə tvei di sterkste vas, tu $\tilde{\theta}$ reisexər met $\tilde{\theta}$ varem mantəl 'om da:r'layes kom. hœl vort dət 'ẽ:s dat di 'e:n, vat di 'e:rste di reisøxər kon no:tsa:k om sei mantel 'af to ha:l, for di sterksto sou ç६ldə. da:rop xa:t di no:rdevent mot 'al sei max an $t$ va:i; mar hu hardər hei va:i, hu faster vəkəl di reisəxər həm $\tilde{\theta}$ sei mantel; $\tilde{\theta}$ 'eindələk çe: di no:rdəvənt mut 'op. tu bө'xən di son warəm skein, $\tilde{\theta}$ ?e:n tve: dri əs di mantəl fan di reisəxər 'af. di no:rdevent mus tu 'er'ken dat di son di sterkste fan di tre: vas.

\section{URDU}

(compare transliteration on p. 32)

$[\mathbf{t}, \mathbf{d}, \mathbf{n}, \mathbf{l}, \mathbf{r}$ are dental; $\mathbf{t}, \mathbf{d}$ are 'inverted' (cerebral). $\mathbf{r}$ is formed by curling back the tip of the tongue and then shooting it forwards so that it makes a single flap against the teeth-ridge (gums). - p, t, c, $\mathbf{k}$ (without following $\mathbf{h}$ ) are unaspirated. In $\mathbf{h h}, \mathbf{d h}, \mathbf{f h}, \mathbf{g h}$ the $\mathbf{h}$ is voiced. - The pronunciation of the 
sounds here represented ly $\mathbf{c}, \boldsymbol{J}$ seems to vary between pure $\mathbf{c}, \boldsymbol{f}$ and the English $\mathbf{t} \boldsymbol{f}$, $\mathbf{d z}$ and the groups tij, $\mathbf{d j}$.

- $\mathbf{i}, \mathbf{e}, \mathbf{0}, \mathbf{0}, \mathbf{u}$, are always long in stressed syllables. $\mathbf{I}, \boldsymbol{U}$ are as in the English it, put; they are always short. $\mathbf{a}$ is a variety somewhat resembling the English $\boldsymbol{\Lambda}$ in much. e, o stand for or, or.]

aftab aor bad I fimal apas mẽ bahəs kar rahe the ki ham dono mẽ se kaon zoravar hae, ki ek mosafir garm coкa oṛhe hue cala aja. unhõ ne apas mẽ ittıfaq kıja ki us musafir ka сона jo pahele vtarva de vohi zoravar samjha jae.

bad I Jimal ne maqdur bhar zor lagaja, magar jjũ jjũ us kI

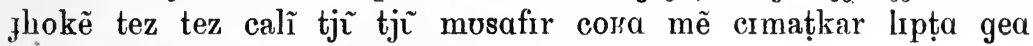
jahã tak ki vttara apne jIhad se baz aja.

phir aftab tezi se $\operatorname{camak}(\theta)$ ne laga, to jhat musafir ne совa vtar dia, aor bad i fimal ko man(e)na paṛa ki ham dono mẽ se aftab zoravar hae.

\section{PANJABI (Northern Mohammedan dialect)}

[t, $\mathbf{d}$, are dental, $\mathbf{n}, \mathbf{l}, \mathbf{r}$ alveolar; $\mathbf{r}$ is formed by a single flap of the tongue. $\mathbf{t}, \mathbf{d}, \mathbf{n}, \mathbf{l}$, are 'inverted' (cerebral); $\mathbf{r}$ as in Urdu; $\mathbf{t} \boldsymbol{j}$, $\mathbf{d z}$ as in Italian ciò, già. $\mathbf{p}, \mathbf{t}, \mathbf{t} \boldsymbol{\int}, \mathbf{k}$ (without following $\mathbf{h}$ ) are unaspirated. - I, $\mathbf{\Lambda}, \boldsymbol{\sigma}$ are as in the English it, much, put. $\mathbf{n}$ tends to nasalize vowels next to it.

${ }^{\wedge}$ represents a peculiar tone of high pitch preceded by a slight rise and followed by a slight fall. In connected speech it often becomes a simple high tone.

c is used provisionally to represent a glottal sound somewhat resembling the Arabic 'ain. It is difficult to say whether this sound is really a consonant or whether it is not rather a low rising tone. When initial it is accompanied by a slight aspiration.]

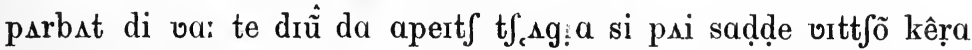

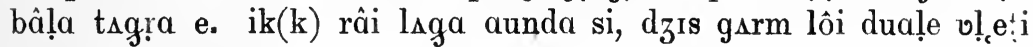
"oi si. ôn ã fæsla kita pai jêra pæal'e râi di lôi $l_{a} \alpha e$, ûoi bâuta tag!a simmdzea dzae. pher parbst di va: pure zor nal osggan! lagi. par dżnna os ț̣l laea onne vîdd zor nạ râi lôi duạ̣e

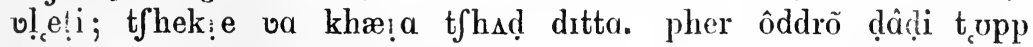
nıkḷ pai. te t $\int_{c} \Lambda t$ p pat os lôi lâ lei. te va: nũ munnṇa pea pai saḍdeã dôã vittfõ drũ̃ taqụa e. 


\section{CHINESE (Cantonese dialect, colloquial style)}

[The six tones are indicated by the signs ' - ..-; for their values see Jones \& Woo, Cantonese Phonetic Reader (London University Press).

- $\mathbf{p}^{\mathbf{e}}, \mathbf{t}^{\mathbf{k}}, \mathbf{t} \mathbf{s}^{\mathbf{2}}, \mathbf{k}^{\mathbf{k}}$ are used for the aspirated consonants $\left(\mathbf{p}^{\mathbf{e}}, \mathbf{t}^{\mathbf{k}}, \mathbf{k}^{\mathrm{e}}\right.$ are much the same as in English); $\mathbf{p}, \mathbf{t}, \mathbf{k}$ are unaspirated and sound to an English ear rather like b, d, g. Final $\mathbf{p}, \mathbf{t}, \mathbf{k}$ are pronounced without explosion. $\mathbf{s}$ is more accurately $\mathbf{s}$. - Final $\mathbf{i}$ is lower and further back than the English vowel in see. i, $\mathbf{u}$ tend towards $\mathbf{e}$, ò when followed by $\mathbf{k}$ or $\mathbf{y}$. i i is used to represent a sound intermediate between $\mathbf{i}$ and $\mathbf{y}$.

- In the diphthongs the second element is the consonantal element. - Length is significant in the case of the sound a.] 'pak'fun_kuy-ko_jit't au, 'hai-ts' y le'tsay_lœn jau'jat-pin,

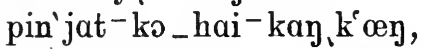
jau'jat-ko,jan, 'hai'ko-ts' y'jat_tsik' kin-kwo.

$\mathrm{k}^{\mathfrak{r}} œ y, \mathrm{l}^{\prime} \mathrm{y}^{\prime} \mathrm{ka}$ - tsau, ts'in'jyn_lap-jœk, jy'kwo'ko-ko,jau'pun_si,

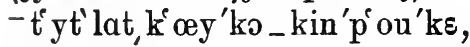

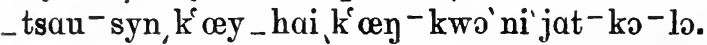

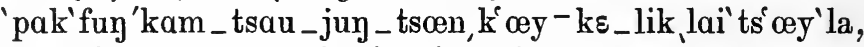
sœy'tsi k’ œy_jyt-fat'ts œy' tak' ka:u'kwa:n, 'ko-ko,jan _jyt-fat'la: m_sat,ke @ _kin'pi ou, wai_tsy, $k^{\prime} \propto y-k \varepsilon^{\prime} \operatorname{san}^{-}$po, 'tsœet' tsi-kin'tak'tu_hai m-tsou'ta(k),lai-ke-lo, 'pak' fun_tsau, m-tsoi-tsai' la.

$$
\text { 'ko_tsan, 'ko-ko_jit'te au, }
$$
-tsau-saii'ts ot_jit-hei'hou,nyn, 'ko-ko, ha:y_lou-ke,jan,

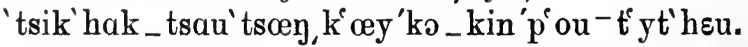

'kam'jœy'ne, 'ko-ko'pak' fun_hai'ka:m_tsy-jiu'tsiu_jin, - wa'ko-ko_jit't $a u$, $-\mathrm{ka \eta}, \mathrm{k} œ \eta-\mathrm{k} \varepsilon, \mathrm{j} \varepsilon-\mathrm{lo}{ }^{1}$ ) _hai, ke œy, lœy-ka'tsi' tsuy,

\section{BURMESE}

$\mathbf{p}^{\mathbf{e}}, \mathbf{t}^{\mathbf{2}}, \mathbf{k}^{2}, \mathbf{s}^{\mathbf{2}}$, strongly aspirated; initial $\mathbf{p}, \mathbf{t}, \mathbf{k}, \mathbf{s}$ unaspirated (p, t, $\mathbf{k}$ being as in French). Final $\mathbf{t}, \mathbf{k}$, ? are pronounced without

1. A literal translation of this passage will be found in the Maître Phonétique, May 1911. 
explosion. - o is nearer to the English than to the French variety. - Vowels are nasalized when followed by nasal consonants. 'denotes a falling tone. Vowels immediately followed by ' are long. a, I, $\boldsymbol{U}, \boldsymbol{\theta}$ and all vowels followed by ? are short; so also is $\varepsilon$ before a final consonant. Otherwise all vowels not in diphthongs are long, and those not followed by ' have an even or rising tone without stress.]

mjauk le min' hnın? ne min' di mi du ga? $\theta a$ a' tji' di

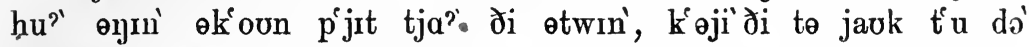
enn'dji go wot hljat la ja, le min' hnın?' ne min' di Savk la

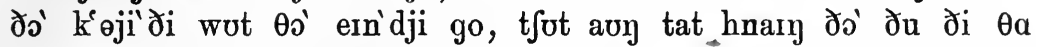

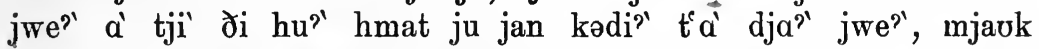

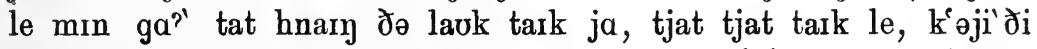
әwot ko hma $\theta$ a kat le, eto tja hma?' le min' di, me tat hnary

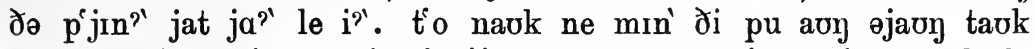

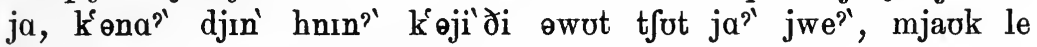

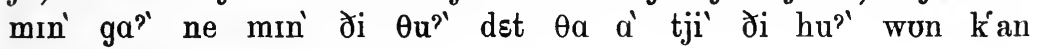
ja? le $\partial{ }^{\prime}{ }^{1}$ )

\section{PHONETIC SPELLING}

The utility of the International Phonetic Alphabet is not confined to the actual representation of pronunciation. The system may also be used (with suitable conventions) as a general system. of spelling for any language, and as a means of transliteration of the native spelling of many languages. We give here an example of phonetic spelling of English. This form of spelling is based on the principle that it should be capable of being easily read and written by speakers of any dialect. For various reasons it is found expedient to choose Northern English pronunciation as the basis for this system of spelling. By making a few obvious conventions, however, the system is practically phonetic for speakers of Southern English and other dialects.

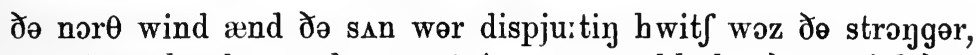
hwen $\theta$ trævəler ke:m eloy ræpt in $\theta$ worm klo:k. de: өgri:d ðæt

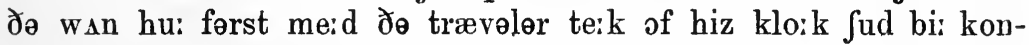

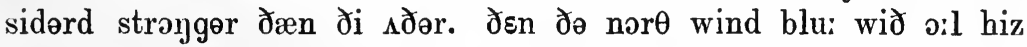

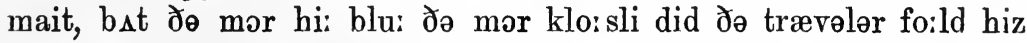

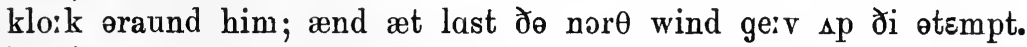

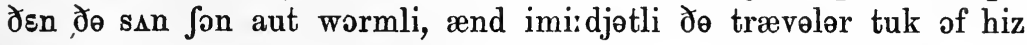

1. A literal translation of this passage will be found in the Maitre Phonétique, Jan. 1912. 


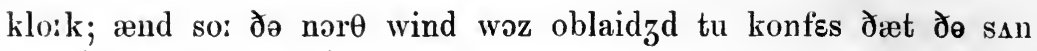
woz də stroygər ov də tu:.

We give also a transliteration (as nearly as is possible) of the native spelling of $\mathrm{Urdu}^{1}$ ). It is instructive to compare this text with the phonetic transcription given on p. 29.

'a:fta:b 'aur ba:d ?i fima:l 'a:pas mẽ bahs kar rahe the ki ham dono mẽ se ka:un zora:var hai, ki 'ek musa:fir garm cosa: 'oṛhe hu:'e cala: 'aija:. 'unhõ ne 'g:pas mẽ 'ittifa:q kija: ki 'us musa:fir ka: сова: jo pahle 'atarva: de vuhi: zora: var samfha: ja:?e.

ba:d i fima:lo ne maqdu:r bhar zor laga:ja:, magar jjũ ґjũ 'us ki Jhokẽ tez tez calĩ tjĩ tjũ musa:fir cora: mẽ cimaṭkar lipṭa: gaja: jahã tak ki 'uttara: 'apne jihad se ba:z 'a:ja:.

phi:r 'a:fta:b tezi: se camakne laga: to Jhat musa:fir ne сока: 'uta:r dija:, 'aur ba:d 'i fima:l ko ma:nna: para: ki ham dono mẽ se 'a:fta:b zora:var hai.

\section{A LIST OF THE PRINCIPAL WORKS IN, WHICH THE INTERNATIONAL PHONETIC ALPHABET IS EMPLOYED}

Books marked with an asterisk may be obtained by members of the Association at half price on application to the headquarters of the Association.

b. denotes 'bound', p. 'paper cover'.

\section{General Phonetics.}

W. Viftor \& W. Rippmann, Elements of Phonetics. London (Dent) 1899, 2s. 6d. W. Scholde \& E. Sмгтн, Elementary Phonetics. London (Blackie) 1903, 2s. 6 d. B. Dumville, The Science of Speech. London (Clive), 2s. 6d.

L. Sonmes, Introduction to Phonetics. London (Macmillan) $2^{\text {nd }}$ ed., 1912, 6s.

P. PAssy, Petite phonétique. Leipzig (Teubner) $2^{\text {nd }}$ ed., 1912, p. M. 1.80, b. M. 2.20.

W. Vietor, Elemente der Phonetik. Leipzig (Reisland) $5^{\text {th }}$ ed., 1904, p. M. 7.20, b. M. 8.-

W. Vistor, Kleine Phonetil." Leipzig (Reisland) $3^{\text {rd }}$ ed., 1903, p. M. 2.50, b. M. 2.80 .

O. Jespersen, Lehrbuch der Phonetik. Leipzig (Teubner) 1904, p. M. 5.-, b. M. 5.60 .

O. Jespensen, Phonetische Grundfragen. Leipzig ('Teubner) 1905, p. M. 3.60, b. M. 4.20 .

1. The vowel symbols have to be supplied, the vowels not being satisfactorily represented in the native writing. 'The sounds represented in the phonetic rendering (p. 29) by $\mathbf{i}$, $\mathbf{r}$, are here distinguished as long and short $\mathbf{i}$, following the system of transliteration of the Royal Asiatic Society. So also with the other pairs of vowels. 
O. Jespersen, Elementarbuch der Phonetik. Leipzig (Teubner) 1912, p. M. 2.-, b. M. 2.60 .

H. Klinghardt, Artikulationsïbungen. Cöthen (Schulze) 1897, M. 5.50.

Passy \& Jones, Alphabet organique, 1907. 6d. Obtainable only from the Secretaries of the Phonetic Association.

\section{Phonetics of single languages.}

(i). English.

D. Jones, The Pronunciation of English ${ }^{1}$ ). Cambridge 1909, 2s. 6d.

D. Jones, An Outline of English Phonetics (for foreign students). Leiprig (Teubner). In preparation.

W. Rippmann, The Sounds of Spoken English. London (Dent), 1s. 6d. for children.

, English Sounds. London (Dent), 1911, 1s. Designed specially

L. H. Authaus, The Sounds of the Mother Tongue. London University Press, 1912. Designed specially for children. 2s. Exercises only, 6d.

A. Western, Englische Lautlehre. Leipzig (Reisland) $3^{\text {rd }}$ ed., 1912, M. 3.-. Pн. Wagner, Die Sprachlaute des Englischen. Stuttgart (Neff) $3^{\text {rd }}$ ed., 1899. M. 3.-.

R. J. Lroyd, Northern English ${ }^{1}$ ). Leipzig (Teubner) $2^{\text {nd }}$ ed., 1908, M. 3.20. W. Grant, The Pronunciation of English in Scotland ${ }^{1}$ ), Cambridge, 1912.

\section{(ii). French.}

${ }^{*}$ P. PAssy, Les Sons du Français ${ }^{1}$ ). Paris (Didier) $7^{\text {th }}$ ed., 1912, 1 fr. 50. $" \quad$, The Sounds of the French Language ${ }^{1}$ ). Oxford, 1907, 2s. 6d.

K. Nyrop, Manuel du Français parlé. Copenhagen and Paris (Picard), 1912. $4 \mathrm{fr}$.

L. Bascan, Prononciation et Lecture Francaises ${ }^{1}$ ). Rambouillet (Institut de Phonétique Française) 1912, 3 fr. 25.

B. Dumville, French Pronunciation and Diction ${ }^{1}$ ). London (Dent) 1904, 2s. 6 d.

F. Beyer, Französische Phonetik. Cöthen (Schulze) $3^{\text {rd }}$ ed., 1908, p. M. 4.80, b. M. 5.80 .

K. QuienL, Französische Aussprache. Leipzig (Teubner) $5^{\text {th }}$ ed., b. M. 5.80, p. M. 5.-

A. Satllens \& E. Holme, French Pronunciation ${ }^{1}$ ). London (Blackie) 1910, 2s. 6d.

G. Nichouson, Elementary French Phonetics. London (Macmillan) 1909, 3s. 6d.

H. Scrimid, Franzósische Schulphonetil. Cöthen (Schulze), 1909, p. M. 1.50, b. M. 1.80 .

(iii). German.

W. Vietor, Die Aussprache des Schriftdeutschen. Leipzig (Reisland) $7^{\text {th }}$ ed., 1909 , p. M. 2.-, b. M. 2.20.

W. Vietor, German Pronunciation. Leipzig (Reisland) $3^{\text {rd }}$ ed., 1903, b. M. 2.p. M. 1.60 .

E. KAPER, Kortfattet tysk Fonetik. Copenhagen (Gyldendal) 1905.

(iv). Miscellaneous languages.

A. R. G. Vianna, Portugais ${ }^{1}$ ). Leipzig (Teubner) 1903, M. 4.-

E. R. Edwards, La Langue Japonaise parlée ${ }^{1}$ ). Leipzig (Teubner) 1903, M. 8.-

1. Contains some phonetic texts. 
A. Frinta, Novočeská Výslovnost (phonetics of ('zech) ${ }^{\mathbf{1}}$ ). Praze, 1909.

D. Jones, The Pronunciation and Orthography of the Chindau Language (South Africa). London University Press 1911, 18.

G. Panconcelli-Calzia, Italiano ${ }^{1}$ ). Leipzig (Teubner), 1911, M. 4.-

R. Сh. Guernier, Notes sur la Prononciation de la Langue Mandarine parlée. International Phonetic Association, 1912. 1s.

L. Ščerba, Court Exposé de la Prononciation Russe. International Phonetic Association, 1911. $7 \mathrm{~d}$.

\section{Phonetic Reading-matter.}

(i). English.

D. Jones, Phonetic Readings in English. Heidelberg (Winter) 1912.

" , Phonetic Transcriptions of English Prose. Oxford 1907, 2s.

W. Rippman, Specimens of English. London (Dent) 1908, $1 \mathrm{s.}$

G. E. Funrkex, Transcription of Jespersen-Rodhe Engelsk Läsebok. Stockholm. (Fritze) $1907,2 \mathrm{kr} .50$ (=3 s.).

H. Sмiтн, Transcription of Shindler's Echo of Spoken English. Marburg 1908, M. 1.50 .

E. R. Edwands, Transcription of Viëtor-Dör Englisches Lesebuch. Leipzig (Teubner) 1901, M. 2.20.

G. Noel-Armfield, 100 Poems for Children. Leipzig (Teubner) 1910, M. 1.90. See also the books marked ${ }^{1}$ ) in group II.

\section{(ii). French.}

C. Motre, Lectures Phonétiques. Paris (Didier) 1912, 2 fr. 50.

P. PAssy, Choix de Lectures. Cöthen (Schulze) 1904, 80 pf.

$" \quad$, Le Français parlé. Leipzig (Reisland) $5^{\text {th }}$ ed., 1897, M. 1.80.

* ", Lectures Variées. Paris (Société des Traités, 33 rue des Sts. Pères) $2^{\text {nd }}$ ed., 1 fr. 50.

*P. Passy, Versions populaires du Nouveau Iestament. Paris (Société des Traités) 1893-96, $2 \mathrm{fr}$.

J. PAssy \& A. RambeaU, Chrestomathie francaise. Leipzig (Teubner) $3^{\text {rd }}$ ed., 1908, 6 fr.

D. Jones, 100 Poésies Enfantines. Leipzig (Teubner) 1906, b. M. 2.20, p. M. 1.80.

Th. Rosset, Exercises pratiques d'articulation et de diction. (Grenoble) $3^{\text {rd }}$ ed., 1912. (Brown cover edition $\left.{ }^{2}\right)$ ).

G. Thudichum, Manuel de Diction. Geneva (Kündig) $4^{\text {th }}$ ed., 1912, $5 \mathrm{fr}$.

E. Simonsen, Franske Lydskrifttexter. Copenhagen. $\mathrm{Kr} .1 .25$ (=1s. 5d.).

V. Spiers, Senior French Reciter. London (Simpkin \& Marshall) 1902, 1s. 4d.

S. A. Richards, Phonetic French Reader. London (Dent), 1s. 6d.

A. Zünd-Burguet, Exercices Pratiques de Prononciation Française. Marburg (Elwert).

V. Partington, Récitations et Poésies. London (Marshall), 1903, 2s.

See also the books marked $^{1}$ ) in group II.

(iii). German.

W. VIET OR, Lesebuch in Lautschrift. 1. \& 2. Teil. Leipzig (Teubner) M. 3.- each. " , Kleines Lesebuch in Lautschrift. Leipzig (Teubner), M. 0.80.

1. Contains some phonetic texts.

2. The edition in grey cover uses another system of transcription. 
A. Egan, A German Phonetic Reader. London University Press, 1913.

Prerce \& Hempl, Wilhelm Tell. New York (Hinds-Noble).

E. A. Meyer, Deutsche Gespräche. Leipzig (Reisland), 1906.

(iv). Miscellaneous Languages.

D. Jones \& Kwing Tong Woo, A Cantonese Phonetic Reader. London University Press, 1912.

Djelaur \& Passy, Chants et Contes Arméniens. Paris (Société des Traités, 33 Rue des Saints Pères) 1899, 0 fr. 50.

A. Vianna, Extraits des Lusiades. International Phonetic Association, 1892, 0 fr. 50.

A. Camill, An Italian Phonetic Reader. London University Press. (In preparation).

P. PAssy, Évangile de Marc, texte grec. Paris (Société des Traités, 33 Rue des Saints Pères) 1898, 1 fr. 50.

J. SPIEser, Hebräische Lautschrifttexte. International Phonetic Association, 1898, 0 fr. 50.

J. J. Sмттн, An African Dutch Phonetic Reader. London University Press. (In preparation).

Atrinson \& Prarce, First Latin Book. London (Dent), 3s. Phonetic Transcriptions only, $6 \mathrm{~d}$.

H. Forchnammer, A Danish Phonetic Reader. London University Press. (In preparation).

\section{Modern Language Text Books, Grammars, etc.}

(i). Finglish.

W. Rippmann, First English Book. London (Dent) $4^{\text {th }}$ ed., 2s.

Haberland's Unterrichtsbriefe, Englisch, ed. by Thiergen \& Cray. Leipzig (Haberland) and Berlin (Mentor Verlag). In 24 parts, price M. 1.- each.

* P. Passy, Eléments d'Anglais parlé. Paris (Société des Traités, 33 rue des Sts. Pères) $3^{\text {rd }}$ ed., 1 fr.

F. Jones, A First English Course. London (Blackie), 1910, 2s. 6d.

L. Sonmes, Phonetic Method for learning to read. (Teachers Manual). 2 vols. London (Macmillan) $2^{\text {nd }}$ ed., 1912, 2s. 6d. each vol.

Рн. WAGNer, Lehr- und Lesebuch der englischen Sprache. Stuttgart (Bonz) $4^{\text {th }}$ ed., 1910.

E. A. Torfau de Marney, First Step to English Conversation. Leipzig (Haberland), 1903, M. 1.-.

G. Camerlynck, Girls' Own Book. Paris (Didier), 2 fr. 50.

$" \quad$, Alice in England. Paris (Didier), 2 fr. 50.

" , Miss Rod. Paris (Didier), 2 fr. 50.

" , First Steps in English. Paris (Didier), 1 fr. 50.

Diesterweg's Neusprachliche Reformausgaben. Edited by M. F. MANN, Frankfurt. Several volumes, e. g.

Kingsley's Water-babies, ed. by M. Duve.

T. W. Robertson's 'Caste', ed. by F. JANoske.

Modern British Problems, ed. by M. Montgomery.

Chambonnaud \& Texier, Fred and Maud. Paris (Dunot \& Pinat), 1911, 3 fr. 25.

Thiergen \& Hamman, English Anthology. Leipzig (Teubner), 1911, M. 2.-.

L. Sorzano Jorrin, Libro Primero de Ingles. Habana, Cuba, 1910. 
Marseille \& Schmid, Englische Grammatik. Marburg (Elwert), 1912, M. 2.-.

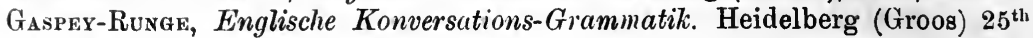
ed., M. 3.60.

Mauron-V Vrrifr, Grammaire Anglaise. Heidelberg (Groos) $10^{\text {th }}$ ed., M. 3.60.

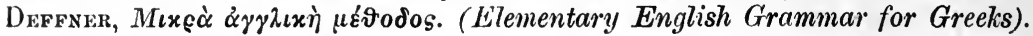
Heidelberg (Groos), M. 3.-.

Peтrowitsch, Kleine Englische Sprachlehre für Serben. Heidelberg (Groos), M. 2.40 .

F. S. Dremer, English Literature from Beowulf to Bernard Shaw. Berlin (Weidmann) $2^{\text {nd }}$ ed., 1911, M. 2.60.

F. Künschner, Englische Umgangs- und Geschäftssprache. Leipzig (Huberti) M. 2.75 .

\section{(ii). French.}

Alge \& Rippana, First French Book (Phonetic part). London (Dent), 6d. Alge \& Rippmane, Second French Book. London (Dent), 2s.

D. L. Savory, Phonetic Edition of Kirkman's Première Année de Francais. London (Black), $6 \mathrm{~d}$.

D. L. SAvony, Phonetic Edition of Calvert and Hartog's French Oral Teaching. London (Rivingtons), 1s.

Mackay \& Cuntrs, First and Second French Boolis. London (Whittaker). First Book, 1s., Second Book, 1s. 6d.

W. E. Llewellyn, French Primer (Phonetic Edition). London (Dent), Sd.

H. E. Berthon, Première Grammaire Française. London (Dent), 2s.

A. Thovallue, First Steps in Colloquial French. London (Blackie).

D. L. Savory, Trois Semaines en France. Oxford (Clarendon Press).

Mrs. J. G. Frazer, Je sais un Conte. Oxford (Clarendon Press).

J. S. Walters, Episodes en action. London (Dent), 1s. 4d.

H. Hultenberg, Extraits de Tristan Bernard, Mémoires d'un jeune homme rangé. Stockholm (Norstedt).

Beyer \& Passy, Elementarbuch des gesprochenen Französisch. Cöthen (Schulze) $2^{\text {nd }}$ ed., 1904, M. 2.80.

Boerner \& Schmitz, Lehrbuch der französischen Sprache. Leipzig (Teubner). Teil I: M. 1.80; Teil II: M. 2.80; Oberstufe: M. 3.60.

Отто \& Runge, Französische Konversations - Grammatik. Heidelberg (Groos) $28^{\text {th }}$ ed., M. 3.60 .

Tн. Gounscнмпт, Fransk Billed-Gloser. Copenhagen (Gyldendal), Kr. 2.65 (=3s.).

P. Mотті, Gramatica elementare francese. Heidelberg (Groos), $4^{\text {th }}$ ed., M. 2.-. Coster, Kleine Engelsche Spraakkunst. Heidelberg (Groos) M. 2.- .

M (Groos), M. 3.60.

TANTY, Gramatica francesa. (For Spaniards). Heidelberg (Groos), M. 4.-

Hermanstorff \& Wallem, Fransk Elementarbog. Kristiania (Aschehoug), 1901,48 .

Fraser \& Squalr, Practical French Grammar. London (D. C. Heath), 1911, 3s. $6 \mathrm{~d}$.

(iii). German.

E. Orто, German Conversation-Grammar. Heidelberg (Groos) $29^{\text {th }}$ ed., 1911, 4s.

A. Thouallie \& E. Nonnenmacher, Primer of Colloquial German. London (Philip), 2s. 6d.

Rippahan, Alge \& Hamburger, First German Book. London (Dent), 2s 6d. 
E. Freudenthar, Grundlegendes Lehrbuch des Deutschen. Helsingfors.

D. L. Savory, Drei Wochen in Deutschland. Oxford (Clarendon Press), 2s. 6d. " , Easy German Texts. 6 vols. London (Rivingtons), 1s. each vol. ", Deutsches Reform-Lesebuch. Oxford (Clarendon Press), 2s. 6d.

G. 'T. UNGOed, First German Book. Cambridge University Press, 1912.

Gawnissx, Kleine deutsche Sprachlehre für Bulgarien. Heidelberg (Groos), M. 2.40 .

Otro \& Prevôt, Grammatica Allemã. For Portuguese students. Heidelberg (Groos), M. 4.-.

Deelmann, Neuhochdeutsch für Niederländer. Breda 1902.

O. Nobrung, Primeiro livro de alemão. São Paulo, 1901, 7s. 6d.

НАuғf, Нъмецкая Грамматика. Heidelberg (Groos) $2^{\text {nd }}$ ed., M. 3.60.

(iv). Miscellaneous Languages.

H. Forchhammer, How to learn Danish. Copenhagen(Gyldendal), $2 \mathrm{kr}(=2 \mathrm{~s}$. 3d.) $" \quad$, Le danois parlé. Heidelberg (Groos), 1911, M. 2.- .

, ，Dänischer Sprachführer. Heidelberg (Groos), M. 2.-.

E. G. Thомаs, Danish Conversation Grammar. Heidelberg (Groos), 1911. M. 6.-

WALter, Schwedische Konversations-Grammatik. Heidelberg (Groos), M. 4.80. F. Roвert, First Spanish Book. London (Dent), 2s.

SAUER \& Ruppert, Spanische Konversations-Grammatik. Heidelberg (Groos) $10^{\text {th }}$ ed., M. 4.-.

Forster, Latin Primer. London (Dent), $1 \mathrm{s.}$

J. M. Hoogviris, Elements of Dutch. The Hague (Nijhoff) $7^{\text {th }}$ ed., 1910. $3 \mathrm{~s} .9 \mathrm{~d}$.

R. Еквцом, Rysk Grammatik. Stockholm (Bonnier), 1911.

P. Moтri, Russian Conversation Grammar. Heidelberg (Groos), 6s.

Fuchs, Russische Konversations-Grammatik. Heidelberg (Groos), M. 5.-.

GaWRIYSKY, Bulgarische Konversations-Grammatik. Heidelberg (Groos), M.4.60.

Wicherkiewicz, Polnische Konversations-Grammatik. Heidelberg (Groos) $3^{\text {rd }}$ ed., M. 4.60.

MASchner, Tschechische Konversations-Gramatik. Heidelberg (Groos), M. 5.-. I. Ex, Portuguese Conversation Grammar. Heidelberg (Groos), M. 5.-.

Kont, Petite Grammaire Hongroise. Heidelberg (Groos), M. 2.-.

$\mathrm{N}_{\mathrm{AGY}}$, Kleine ungarische Sprachlehre. Heidelberg (Groos) $2^{\text {ad }}$ ed., M. 2.-.

VALETTE, Kleine niederländische Sprachlehre. Heidelberg (Groos) $3^{\text {rd }}$ ed., M. 2.-

\section{Conversation Manuals for Travellers.}

Moтт, Traveller's Companion, German. Heidelberg (Groos), 80 pf.

", Reisebegleiter, Englisch. Heidelberg (Groos), 80 pf.

", " Französisch. Heidelberg (Groos), 80 pf.

$", \quad, \quad$ Italienisch. Heidelberg (Groos), $80 \mathrm{pf}$.

\section{Dictionaries.}

D. Jones, An English Pronouncing Dictionary. London (Dent). In preparation.

H. Michaelis \& D.Jones, An English Phonetic Dictionary. Hannover (Mejer). Ziegler \& Seiz, Englisches Schuluörterbuch. Marburg (Elwert), 1912, M. 4.50. 
R. M. Pience, Dictionary of Hard Words. New York (Dodd, Mead \& C $^{\circ}$ )

R. Pierce, French and English Dictionary. London (Jack), 7s. 6d.

H. Michaelis \& P. Passy, Dictionnaire Plionétique Français. Hannover (Meyer), p. M. 4.-, b. M. 4.80. $2^{\text {nd }}$ ed. in preparation.

E. Pғонц, Neues Wörterbuch der französischen und deutschen Sprache. Leipzig (Brockhaus), 1911, M. 7.-.

W. Vietor, Deutsches Aussprachewörterbuch. Leipzig (Reisland), 1912, M.12.-.

G. Le Boucher, Wörterbuch der italienischen Umgangssprache. Vienna (Hartleben), $2 \mathrm{~s}$.

H. Michaelis, Ergänzungsheft zu Mïller's Wörterbuch der Eigennamen, 7. Aufl. Leipzig (Haberland).

Rangel-Nielsen, Fransk Dansk Ordbog. Copenhagen (Bojesen), 1903.

Boerner \& Schmitz, Französisch-deutsches und deutsch-französisches Wörterbuch. (Supplement to the Lehrbuch der französischen Sprache by the same authors). Leipzig (T'eubner), 1905.

\section{Pedagogy.}

O. Jespersev, How to teach a foreign language. London (Swan Sonnenschein), 1904 , 3s. $6 \mathrm{~d}$.

V. Partington, The Transition from Phonetic to Ordinary Spelling. International Phonetic Association, 7d.

W. Rippanan, Hints on teaching French. London (Dent), 18. 6d.
$" \quad$, Hints on teaching German. London (Dent), 1s. 6d.

Lenz \& Diez, Ensenanza inductiva del frances. Santiago de Chile (Corvantes), 1894.

W. Vietor, Einfïhrung in das Studium der Englischen Philologie. Marburg (Elwert) $4^{\text {th }}$ ed., 1910.

\section{Historical Phonetics.}

O. Jespersen, Modern English Grammar. Heidelberg (Winter). $1^{\text {st }}$ vol., M. 9.Other vols in preparation.

John Hart's Pronunciation of English. Heidelberg (Winter), M. 3.20.

W. VIETOR, Shakespeare's Pronunciation, 2 vols. Marburg (Elwert), 1906. Vol. I, M. 6.-, Vol. II, M. 3.60.

D. Joxes, Scenes from Shakespeare in the original pronunciation. International Phonetic Association, 10d.

K. Nyrop, Grammaive Historique de la Langue Francaise, 3 vols. Copenhagen (Gyldendal) and Paris (Picard), $10 \mathrm{fr}$. each vol.

A. BAKer, Historical French Grammar. London (Dent), 1900, 2s. 6d.

Bertion \& Starkey, Tables Synoptiques de Phonolugie de l'Ancien Français. Oxford, 1908, 2s. 6d.

*P. Passy, Les Changements Phonétiques du Language. Paris (Société des Traités, 33 Rue des Saints Pères), 1891. 8 fr.

\section{Dialectology.}

I. Monf, Zur sprachlichen Gliederung Frankreichs. Berlin (Reimer), 1911. J Ean PAssy, Origine des Ossalois. Paris (Bouillon), 1904, $5 \mathrm{fr}$.

K. Fester, Satzphonetik im Wallonischen Dialekt Malmedys. Halle (Karras), 1911. 
G. L. Cleve, Die Sprache in der wir geboren sind. Berlin (Meyer \& Wunder), $1902,50 \mathrm{pf}$.

J. GEDDEs, Study of an Acadian French dialect. Halle (Niemeyer).

\section{Experimental Phonetics.}

E. A. Mryer, Englische Lautdauer. Leipzig (Harrassowitz), 1903, M. 2.", Untersuchungen ïber Lautbildung. Marburg 1910.

E. Scriptcre, Spcech Curves. Washington (Carnegie Institution), 1906.

\section{Elocution.}

C. M. RIcE, Voice Production with the aid of Phonetics. Cambridge (Heffer), 1912, 1s. 6d.

\section{Versification.}

P: Verrier, Principes de 7 a Métrique Anglaise, 3 vols. Paris (Welter), 1910. $47 \mathrm{fr} .50$ for the 3 vols.

\section{Intonation.}

Kuinghardt \& De Fourmestraux, Französische Intonationsïbun: Cöthen (Schulze), 1911, M. 3.80.

D. Jones, Intonation Curves. Leipzig (Teubner), 1909. M. 2.60.

\section{Periodicals.}

Le Maitre Phonétique, organ of the International Phonetic Association. Editor P. PAssy, assistant editor D. Jones. Free to members of the Association. Price through a bookseller 4s. per annum.

Modern Language Teaching, organ of the Modern Language Association. Editor J. G. Anderson. London (Black).

Die Neueren Sprachen. Editor W. Vifror. Marburg (Elwert), M. 12.- per annum.

Revue de l'Enseignement des Langues Vivantes. Edited by H. Lorseau and G. Camerlynck. Paris (Didier), 12 fr. (abroad 15 fr.) per annum.

\section{Sound Charts.}

W. Vietor, Lauttafeln (English, French, German). Marburg (Elwert). Wall charts M. 2.- each; on linen M. 4.-. Small size (for students), $10 \mathrm{pf}$ each.

W. RIPpyane, The Sounds of English London (Dent). " , Les Sons du Francais Paper 1s. each;

$" \quad$, Deutsche Laute mounted with rollers 2s. 6d. each.

D. Jones, Englisit Speech Sounds \} Cambridge University Press. Paper 1s.6d. " , Les Sons du Français $\}$ each; mounted with rollers 3s. each. " , A small chart of English speech sounds, with key words and notes. Oxford University Press, $4 \mathrm{~d}$.

F. Rauscr \& D. Jones, Sound Charts. A set of 9 charts showing the positions of the organs of speech in pronouncing the principal vowels. London (Dent), 12s. $6 \mathrm{~d}$. the set.

W. Scholle \& G. Sмitr, Coloured Wall Charts of English, French and German Sounds. London (Blackie), 2s. each; on linen 4s. 6d. cach.

Malagoli \& Calzia, Tabella dei suoni italiani. Marburg (Elwert), 20 pi.

E. РАEgLe, 'Таблцца русскихъ звуковъ (small chart of Russian Sounds). Riga, 1910. 
SCRIPT FORMS

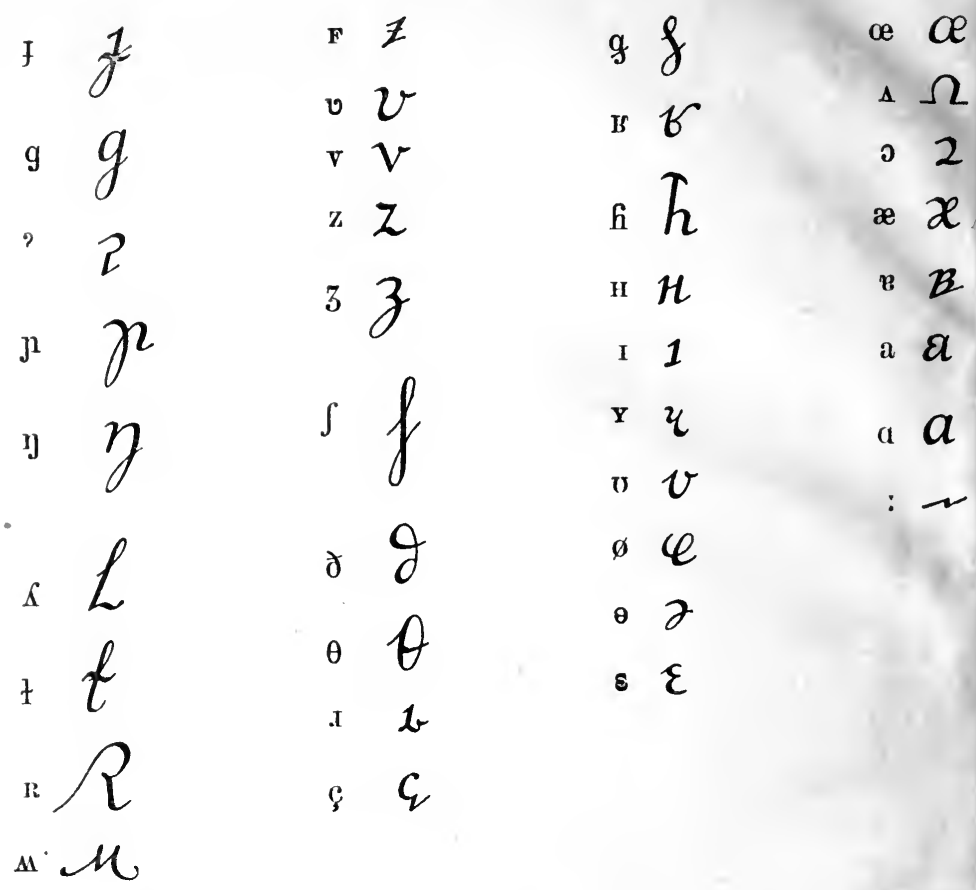

ч

SPECIMEN OF PHONETIC WRITING

The following is the script form of the passage in phonetic spelling given on p. 19.

Or nsert wind and or an wor dispjuating hwitf wax of straygar hwen a travslse kem olsy rept in a warm klask. De agrind bet \& wan hur frost med or travslse terk of hir klork fud bi konsidsed itrsygar den disore. In or wart wind blu wit al hix mait, bot os mser his the os mar klasli did of trsershs foold his klork rround him; and st last or nert wind gew sp bi stempt. Den bo san fan out wasmli, and imindjstli os trserslse tuk of hix klork; and so fo narl wind was oblaidzd the konfes bet is and was is stesyges ar is tus. 


\section{NOTICE TO MEMBERS OF THE INTERNATIONAL PHONETIC ASSOCIATION.}

\section{The Journal.}

Communications relating to the journal should be addressed to Paul Passy, 20 Rue de la Madeleine, Bourg-la-Reine (Seine), France (for French and Romance languages), or to Daniel Jones, University College, London, W. C. (for other languages). Articles intended for the journal should be written in phonetic characters and very legibly; they should be written on quarto sheets and on one side of the paper only. The International Phonetic Alphabet must be used, but each author is free to employ any language and to represent any style of pronunciation he may prefer. As regards minute shades of sound, authors are requested to indicate the $m$ as far as practicable by means of notes, and not to overload the transcription with diacritical marks. Authors receive a proof of articles inserted in the journal; such proofs should be corrected carefully, without making any important alterations, and sent back to the editor (not to the printer) by return of post. Only communications of members are inserted in the journal.

\section{The administration.}

Communications relating to the admiuistration of the Association should be addressed to Fonetik, Bourg-la-Reine (Seine), France, or to Daniel Jones, University College, London, W. C.

The names of new members are published in the journal, together with the names of those by whom they are introduced. T'he names of active members are preceded by *; the names of life members are followed by $\mathbf{V}$.

Members desiring to notify changes of address should send with their applications the sum of $1 \mathrm{~d}$., and should mention their membership number (given in the January number of the journal).

\section{Missing Numbers.}

Members not receiving any number of the journal should apply for it within one month of the date of publication. Applications made later than this should be accompanied by the sum of $1 \mathrm{~d}$. (1 $\mathrm{d}$. may be sent from abroad by using a reply postcard).

\section{Reviews.}

Authors and publishers of books relating to linguistics or pedagogy desiring to have their works reviewed in the journal should send 2 copies (or one copy if the value of the book exceeds 7 s. 6 d.) to one of the Editors.

\section{Advertisements.}

The scale of charges for advertisements in the journal may be obtained on application to the Advertisement Editor, Monsiear E. Lemaire, 11 Rue Carpeaux, Paris $18^{\circ}$.

The charge for private advertisements is $5 \mathrm{~d}$. per line of 12 words or an equivalent space. Private advertisements should be sent to one of the Editors.

Ordinary members whose subscriptions have been paid before Jan. $1^{\text {st }}$ have the right to 10 lines of advertisement free of charge during the year. Active members have the right to 25 lines, and members of the Council to 50 lines. 


\section{RECENT PUBLICATIONS}

\section{OF THE INTERNATIONAL PHONETIC ASSOCIATION}

The Means of Training in Phonetics available for Modern Language

Teachers. By L. H. Althaus. Price $10 \mathrm{~d}$. To members $5 \mathrm{~d}$.

The Transition from Phonetic to Ordinary Spelling. By V. Partington

Price $7 . d$. To members $4 \mathrm{~d}$.

Scenes from Shakespeare in the Original Pronunciation. By D. Jones

Price $10 \mathrm{~d}$. To members $5 \mathrm{~d}$.

Un Alphabet Organique. Par, Paud Passy et D. Jones. Price $7 \mathrm{~d}$. TC members $4 \mathrm{~d}$.

Court Exposé de la Prononciation Russe. Par L. Ščerba. Price $7 \mathrm{~d}$ To members $4 \mathrm{~d}$.

Notes sur la Prononciation de la Langue Mandarine. Par R. Ch. Gurraner.

Price $1 \mathrm{~s}$. To members $6 \mathrm{~d}$.

\section{In Preparation.}

Index analytique du Maître Phonétique 1889-1912. Par J. L. Rayner Orthographe et Prononciation Tehèque. Par A. Frinta.

Back numbers of the Maitre Phonétique may be had at the following prices:

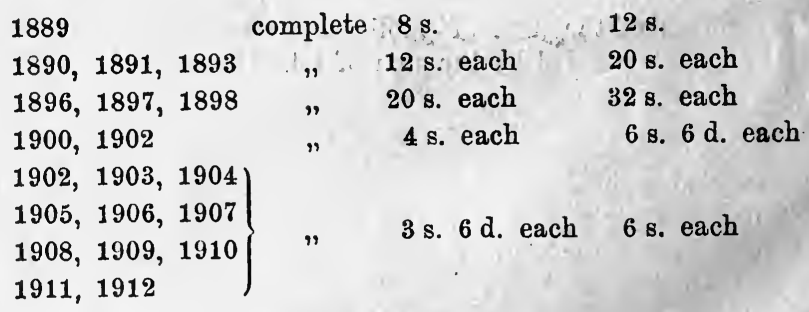

The years $1892,1894,1895,1899$ and 1901 are no longer sold separately.

Complete collections are very rare. There are one or two for sale (1889-1912) price $£ 10$ to members, $£ 14$ to non-members.

Note. The Association is willing to purchase back numbers of the journa prior to 1902. Offers should be addressed to the Assistant Secretary. 


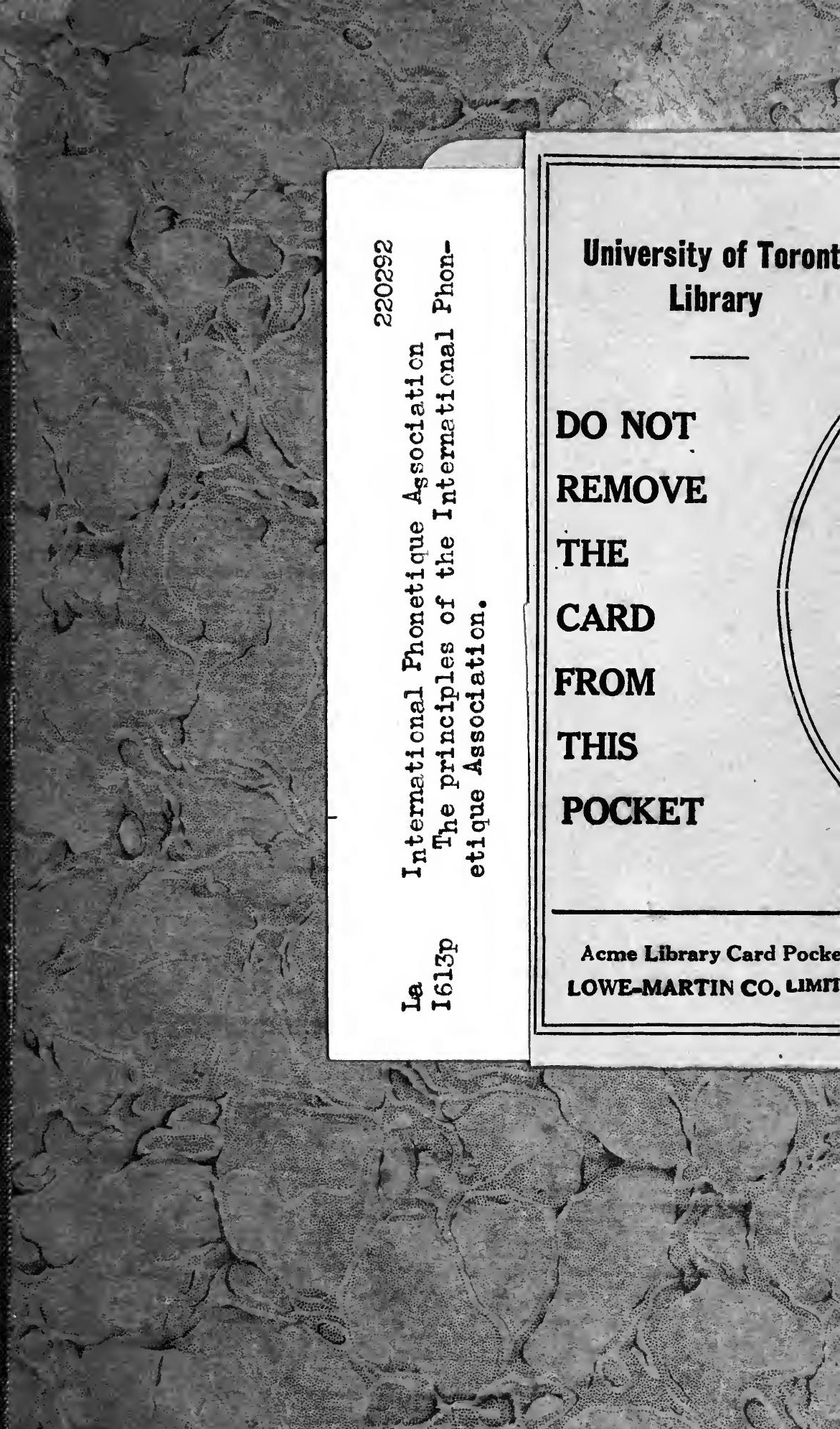


